Article

\title{
The Relation between Past Flows and Future Performance: Simple Investment Strategies in the Mutual Fund Sector
}

\section{Martin Rohleder}

Faculty of Business and Economics, University of Augsburg, Universitaetsstrasse 16, 86159 Augsburg, Germany; E-Mail: martin.rohleder@wiwi.uni-augsburg.de; Tel.: +49-821-598-4120;

Fax: +49-821-598-4223

Academic Editor: Nicholas Apergis

Received: 4 November 2014 / Accepted: 29 January 2015 / Published: 4 February 2015

\begin{abstract}
In the mutual fund literature, it is an established fact that investors "chase past performance". However, the opposite impact of flows on performance is widely discussed. Mainly, liquidity costs are held responsible for short-term erosion of performance, while high inflows enhance performance over longer horizons. I investigate this relation for various groups of equity, bond, and money market funds and find significant outperformance in high inflow funds over several months, especially for specific bond fund groups. In addition, I test whether this information can be exploited using simple investment strategies but find that the abnormal returns are too low to offset associated costs.
\end{abstract}

Keywords: mutual fund performance; fund flows; trading strategies

\section{Introduction and Literature Review}

In the field of mutual funds one important strand of research deals with money flows and the relation between investor flows and performance. Within this area there is broad agreement with the fact that investors "chase performance" (e.g., Ivković and Weisbenner [1,2]; Fulkerson et al. [3]; and public media, e.g., Clements [4]; Gaffen [5]; Israelsen [6]), meaning that fund investors reward superior past performance with new money inflows, while inferior performance is punished by money outflows (e.g., Ippolito [7]). Early studies document a convex, non-linear shape to this relation, showing that good performance leads to high flows of new money while bad performance produces only low outflows (e.g., Chevalier and Ellison [8]; Sirri and Tufano [9]; Del Guercio and Tkac [10]; Shrider [11]). This asymmetry is often attributed to the existence of uninformed (unsophisticated) 
investors making irrational investment decisions (e.g., Gruber [12]), or to the expectation of rational investors that fund firms will replace poorly performing fund managers or at least change their investment strategy to avoid poor performance in future (e.g., Lynch and Musto [13]). Huang et al. [14] also argue that participation costs (information or search costs + transaction costs) are sometimes cited as the reason for staying with a poorly performing fund.

Newer studies on the performance flow relation find evidence for a more linear relation by using gross money flows instead of net money flows. Among others, Ivković and Weisbenner [1] find that "old money” punishes poor performance as much as it awards good performance, but "new money" flows into both poorly performing and well performing funds, thereby disguising the punishment and amplifying the award on an aggregate net flow level. Similar results are documented in studies by Ivković and Weisbenner [2], Shrider [11], Cashman et al. [15,16]. An important reason for these steady new-money flows to poorly performing funds could be the growing popularity of mutual fund-based savings and retirement plans (e.g., Cohen and Schmidt [17]; Holden and Van Derhei [18]; Goda et al. [19]) which, once chosen, are difficult to change.

On the reverse relation between flow and performance, however, there is less agreement in the literature. Ferson and Schadt [20] find that fund flows affect fund betas and thereby the funds' expected returns. As for the direction, Berk and Green [21] argue from a theoretical point of view that the (rational) allocation of new money to previously well performing funds causes diminishing returns to scale, thereby decreasing subsequent performance. On the other hand, poorly performing funds face money outflows and either enhance performance or disappear, such that in equilibrium all surviving funds earn equal returns.

Liquidity service costs and liquidity trading are the most popular explanations for diseconomies of scale caused by fund flows (e.g., Green and Hodges [22]; Coval and Stafford [23]; Edelen et al. [24]; Benson et al. [25]). Besides offering a widely diversified portfolio at a reasonable cost, mutual funds provide a high level of liquidity to shareholders who can buy and sell at the fair net asset value on a daily basis (e.g., Gruber [12]; Edelen [26]). This liquidity service is costly to fund investors, as a fund facing high money inflows might trigger a price impact and therefore have to buy new assets above fundamental value (e.g., Coval and Stafford [23]). This is pronounced for large funds or funds investing in illiquid markets (e.g., Chen et al. [27]; Pollet and Wilson [28]). On the other hand, a fund facing high money outflows is also likely to cause a price impact and may have to sell assets below fundamental value. Interestingly, Coval and Stafford [23] find price impact by liquidity trading ("asset fire sales and purchases”) even in the most liquid of asset markets. In addition, Warther [29], Edelen and Warner [30], and Bhargava and Konku [31] report significant price pressure and price changes in the equity market caused by high aggregate flows to the mutual fund market.

Edelen [26] even finds that it is predominantly due to liquidity service costs that mutual funds usually underperform their benchmarks. Adjusting for liquidity-motivated trading, he finds significant levels of skill among mutual fund managers. Further confirmation of these results is reported in related studies by, e.g., Alexander et al. [32], who analyze returns to trading on information vs. returns to trading on flows. They find significant outperformance for the former and significant underperformance for the latter. Pollet and Wilson [28] analyze the different strategies reacting to growth, specifically scaling vs. diversification. They find that funds reacting to growth by simply scaling 
their existing holdings significantly underperform funds that diversify, especially in more illiquid markets such as small-cap equity.

In recent studies, e.g., Rakowski and Wang [33], Rakowski [34], Benson et al. [25], and Rohleder et al. [35] find that the dynamics in fund flows, high flow volatility and unexpected flows significantly erode fund returns, as these variables cause the fund to perform more liquidity-motivated trades or to hold larger positions of cash as an alternative. However, both Rakowski and Wang [33] and Benson et al. [25] find that price pressure through liquidity trading primarily affects fund returns in the short run. For the long-term, both studies document a positive effect of fund flows on mutual fund returns.

Regardless of its nature, there might be some information content in past mutual fund flows relevant to future returns. In this context, using portfolio holdings, Grinblatt and Titman [36,37] show that mutual fund managers often incorporate momentum in their investment decisions. Thus, if they use new money inflows to purchase past winners, then this might translate into higher fund returns going forward. However, to my best knowledge, there is no study analyzing the relation between flows and performance for a wide variety of different equity, bond, and money market fund groups. In addition, I am aware of no study systematically testing simple investment strategies for exploiting the information content in past fund flows in order to earn abnormal returns, so-called "flow chasing".

In this empirical study I therefore first examine whether there is a significant relation between fund size and performance, specifically economies or diseconomies of scale. Then, I briefly analyze performance persistence or "hot hands" in mutual funds (e.g., Hendricks et al. [38]), because if investors chase past performance, this can only be beneficial if past performance is persistent. After this, I assess whether there is a systematic relation between past flows and future performance for different objectives of equity, bond, and money market funds before testing simple investment strategies based upon this information against uninformed strategies.

I find larger funds to significantly outperform smaller ones, especially among bond and money market funds. In addition, I find significant short-term performance persistence as well as significant performance persistence over longer horizons for money market funds. As for the flow-performance relation, I find high-flow funds significantly outperform low-flow funds over one month, and also find significant outperformance of high-flow funds over longer horizons for bond funds. However, there is no advantage to be gained in using simple investment strategies based upon this information, as the abnormal returns earned by the strategies are eaten up by the high associated costs.

The remainder of this paper is organized as follows. Section 2 describes the methods used in the empirical study. Section 3 describes the data and reports summary statistics and performance. Section 4 presents the results from the empirical study as well as interpreting remarks. Section 5 concludes.

\section{Methodology}

\subsection{Portfolio Construction}

For summary statistics on performance and fund characteristics of different fund groups I construct fund portfolios, or "funds of funds" (Cornell and Green [39]), rather than using individual funds. This is advantageous as it allows the use of data on all funds, regardless of the time series length. In addition, 
it allows the use of beginning-of-month fund size, represented by the fund's total net assets (TNA), directly as weighting factors. The time series also have the same length and cover the same time period, so that market climate bias is of no importance (e.g., Krimm et al. [40]; Breloer and Scholz, [41]).

To assess the impact of fund flows on the performance of different fund groups, I use monthly rebalanced decile-portfolios (e.g., Chen et al. [27]). These are constructed by a monthly ranking of all funds currently existing by their lagged fund flows and value weighting the returns of all funds allocated to a certain portfolio by their beginning-of-month TNA. I follow a similar approach when constructing decile portfolios based upon lagged TNA ranks and on lagged return ranks, respectively.

Note that monthly rebalancing upon lagged fund characteristics might cause look-ahead bias (e.g., ter Horst et al. [42,43]) because funds have to have existed in the past months to be ranked and to be considered for evaluation. Depending on the length of the time lag between ranking period and evaluation period, this means that especially new funds are excluded automatically in their first months or years of existence. However, as new funds are in general very small (e.g., Rohleder et al. [44,45]) and might show incubation bias (e.g., Evans [46]) or ambiguous flows through fast relative growth (e.g., Rakowski [34]) I consider this to be an advantage rather than a problem.

\subsection{Performance Measures}

In my empirical analysis, I use two different types of performance measures. First, I use the mean excess return (MER) which is represented by

$$
M E R_{p}=\frac{1}{T} \sum_{t=1}^{T} r_{p t}
$$

where $r_{p t}$ is the return on fund $p$ in month $t$ in excess of the risk-free rate of return (1-month US T-bill rate). This one-dimensional measure does not account for the risk associated with the realized return. Therefore, I also use multi-factor-models following, e.g., Carhart [47] and Blake et al. [48] to assess the risk-adjusted performance of the respective fund portfolios. These models are represented by

$$
r_{p t}=\alpha_{p}+\sum_{j=1}^{J} \beta_{p j} f_{j t}+\varepsilon_{p t}
$$

where $f_{j t}$ is either the excess return of a long-only benchmark index or the zero-investment return of a long-short factor portfolio $j$ in month $t, \beta_{p j}$ is the coefficient of portfolio $p$ regarding factor $j$, and $\varepsilon_{p t}$ is a normally distributed residual term with zero mean, idiosyncratic to portfolio $p$ in month $t$. The average risk-adjusted excess return is measured by the intercept $\alpha_{p}$ (alpha).

For the different fund groups in my analysis I use different sets of factors as explanatory variables. To equity funds I apply the Carhart [47] four-factor-model containing the excess return on a broad US equity market index (Jensen [49]) as well as the risk factor SMB to capture the small-stock effect, HML to capture the value- vs. growth-stock effect (Fama and French [50]), and MOM to capture the momentum effect in stock returns (Jegadeesh and Titman [51]; Carhart [47]).

To bond funds I apply the MIM-Risk model from Rohleder et al. [45], containing the returns on five indices representing government bonds (BarCap US Aggregate Government), corporate bonds (BarCap US Corporate Investment Grade), mortgage backed bonds (BarCap US Mortgage Backed), municipal bonds (BarCap US Municipal), and high yield bonds (BarCap US High Yield Composite). 
For money market funds. I use four factors representing the return to a broad US bond market index (BarCap US Aggregate Bond) as well as the 1-month, 3-month, and 6-month US Treasury bill rates. Table 1 shows the relevant correlations between these factors/indices.

Table 1. Correlations between factors and indices for multi-factor models.

\begin{tabular}{|c|c|c|c|c|c|c|c|c|c|c|c|c|}
\hline \multicolumn{4}{|c|}{ Equity Funds } & \multicolumn{5}{|c|}{ Bond Funds } & \multicolumn{4}{|c|}{ Money Market Funds } \\
\hline & Mkt - Rf & SMB & HMI & & Govern- & Corpo- & Muni- & High & & Bond & 1-month & 3-month \\
\hline & Mkt - Rt & SIVB & HIVL & & ment & rate & cipal & Yield & & & T-Bill & T-Bill \\
\hline SMB & 22.74 & & & Corp & 70.68 & & & & 1-m. T-Bill & -3.40 & & \\
\hline HML & -25.93 & -30.59 & & Muni & 59.99 & 69.64 & & & 3-m. T-Bill & 18.68 & 5.70 & \\
\hline \multirow[t]{2}{*}{ MOM } & -30.64 & -1.39 & -3.67 & HY & -3.28 & 55.23 & 35.28 & & 6-m. T-Bill & 40.24 & -3.82 & 78.29 \\
\hline & & & & MBS & 86.04 & 72.04 & 63.08 & 13.72 & & & & \\
\hline
\end{tabular}

This table shows correlations between factors and indices for multi-factor models measuring the risk-adjusted performance of equity, bond, and money market funds. Correlation coefficients are denoted in \%. "Mkt - Rf” denotes the equity market excess return, "Corp" abbreviates corporate bonds, "Muni” abbreviates municipal bonds, "HY” abbreviates high yield bonds, "MBS” abbreviates mortgage backed securities and, e. g., “1-m. T-bill” stands for 1-month Treasury bill.

\section{Data}

\subsection{Data Selection and Pre-Processing}

I use data from three different sources in my empirical analysis. Information on open-end mutual fund characteristics such as monthly returns, yearly expense ratios, load charges, first-offer-dates (age), and monthly total net assets (TNA) are from the CRSP Survivor-Bias-Free Mutual Fund Database. Barclays Capital (BarCap) bond and treasury performance indices for the evaluation of bond and money market fund performance are from Thomson Reuters Datastream, and the factors for the Carhart four-factor model are from the Kenneth R. French data library. ${ }^{1}$

The CRSP database provides information on 43,668 US-based mutual funds (December 2009) from which I extract my final sample via a number of screens. First, I use Lipper objective codes and Strategic Insight objective codes to select those funds exclusively categorized as equity, bond, and money market funds between January 1993 and December 2009. ${ }^{2}$ From these, I delete funds without TNA or available return data. In addition, I fill in missing values in the TNA time series of the remaining funds with the three-step procedure from Rohleder et al. [44]. I aggregate multiple-share class funds using CRSP portfolio codes and manual matching by value-weighting returns, loads, and expense ratios, accumulating TNA, and using the oldest share class to determine the funds age. Lastly, I delete those funds with a gap larger or equal to 36 months between first-offer date and first return observation (Rohleder et al. [45]). In total, my dataset contains 8100 mutual funds, of which 4861 are equity funds, 2141 are bond funds, and 1098 are money market funds.

1 http://mba.tuck.dartmouth.edu/pages/faculty/ken.french/data_library.html.

2 Bond funds are further subdivided into "corporate”, “government”, “mortgage-backed”, non-single-state "municipal”, and "general” bond funds. Equity funds are split up into "aggressive growth”, "growth”, "growth/income”, "mid-cap” and "small-cap” funds where I classify, e.g., "small-cap growth funds" as small cap rather than as growth because I consider it the more selective classification with respect to liquidity costs (e.g., Chen et al. [27]; Pollet and Wilson [28]). 
For these funds I calculate monthly absolute (relative) fund flows following Brown and Goetzmann [52] as the difference between end-of-month and beginning-of-month TNA, adjusted by the monthly return over the same month (divided by the beginning-of-month TNA). This definition of relative flows represents the net internal growth of the fund under the assumption that all dividends and other distributions are reinvested (e.g., Berk and Tonks [53]). In addition, it defines relative flows under the assumption that all flows occur at the end of the month. ${ }^{3}$ To avoid biases through extreme relative flows-for example from very small but fast growing new funds-I winsorize relative flows to a maximum of $100 \%$. This way, the respective observation is still in the sample and still indicates a high inflow. Fund flow measures are thus given by

$$
\begin{gathered}
\text { Flow } w_{i t}^{a b s}=\text { TNA }_{i t}-\left(1+R_{i t}\right) T N A_{i, t-1} \\
\text { rel }= \begin{cases}\frac{F l o w_{i t}^{a b s}}{T N A_{i, t-1}} & \\
100 \% & \forall \frac{\text { Flow }_{i t}^{a b s}}{T N A_{i, t-1}} \geq 100 \%\end{cases}
\end{gathered}
$$

\subsection{Summary Statistics}

Table 2 shows summary statistics (Panel A) and performance measures (Panel B) for the funds grouped by their investment objectives in the period from January 1993 through December 2009. In terms of numbers, equity funds are the largest fund group with more than twice as many funds as the bond group and more than four times as many funds as the money market group. In terms of fund size, money market funds are the largest and bond funds are the smallest, so that equity and money market funds show more or less equal total volume in December 2009 while the total volume of all bond funds is smaller. Among bond and equity funds, growth funds are the largest followed by growth/income funds and mortgage-backed bond funds.

In terms of age, money market funds are the oldest followed by bond funds and equity funds. In terms of the expense ratio, equity funds are on average more expensive than bond funds. The "cheapest” funds are money market funds. The most expensive fund asset classes are aggressive growth funds with an expense ratio of $1.65 \%$ p.a. and general bond funds with $1.33 \%$ p.a. Mortgagebacked and municipal bond funds show the lowest expense ratio among bond funds. Among equity funds, growth/income funds are the cheapest. Value-weighted expense ratios are consistently smaller than equal-weighted expense ratios. This suggests that larger funds are cheaper due to economies of scale. The relation is even more pronounced for equity funds.

3 Berk and Tonks [53] define relative flows under the assumption that fund flows occur at the beginning of the month. As in reality fund flows will be spread throughout the month, both assumptions are equally inferior estimates. I believe my assumption is reasonable in the light of the well-documented chasing behavior of investors (e.g., Ivković and Weisbenner [1,2]; Fulkerson et al. [3]). 
Table 2. Summary Statistics and Performance.

\begin{tabular}{|c|c|c|c|c|c|c|c|c|c|c|c|c|c|}
\hline & \multicolumn{6}{|c|}{ Bond Funds } & \multicolumn{6}{|c|}{ Equity Funds } & \multirow{2}{*}{$\begin{array}{c}\text { Money } \\
\text { Market Funds }\end{array}$} \\
\hline & All & Corporate & Government & $\begin{array}{c}\text { Mortgage } \\
\text { Backed }\end{array}$ & Municipal & General & All & $\begin{array}{l}\text { Aggressive } \\
\text { Growth }\end{array}$ & Growth & $\begin{array}{l}\text { Growth/ } \\
\text { Income }\end{array}$ & Mid-Cap & Small-Cap & \\
\hline \multicolumn{14}{|c|}{ A. Summary Statistics } \\
\hline Number of funds & 2141 & 1040 & 396 & 127 & 490 & 88 & 4861 & 308 & 1987 & 1156 & 515 & 895 & 1098 \\
\hline Size [mio US\$] & 636 & 663 & 341 & 1059 & 641 & 800 & 817 & 692 & 863 & 1476 & 274 & 398 & 2293 \\
\hline Total volume in 12/2009 & $1,414,431$ & 892,073 & 87,208 & 93,180 & 291,239 & 50,730 & $2,632,994$ & 96,694 & $1,022,425$ & 983,737 & 203,148 & 326,991 & $2,985,147$ \\
\hline Expense ratio equal [\% p.a.] & 0.8437 & 0.8379 & 0.8865 & 0.8158 & 0.7870 & 1.3320 & 1.2550 & 1.6567 & 1.2655 & 1.0443 & 1.3206 & 1.3313 & 0.5599 \\
\hline Expense ratio value [\% p.a.] & 0.7411 & 0.7660 & 0.7952 & 0.5948 & 0.6605 & 1.3150 & 0.8510 & 1.1693 & 0.9638 & 0.6382 & 1.0037 & 1.0839 & 0.4638 \\
\hline Age [months] & 124 & 116 & 120 & 139 & 146 & 86 & 98 & 96 & 104 & 124 & 54 & 80 & 143 \\
\hline Absolute flow [MUS\$ p.m.] & 2.67 & 4.32 & 0.43 & -1.90 & 1.79 & 5.75 & 3.63 & 2.91 & 4.00 & 4.44 & 3.10 & 2.08 & 13.66 \\
\hline Relative flow [\% p.m.] & 1.06 & 1.36 & 0.77 & 0.31 & 0.83 & 2.24 & 2.33 & 2.72 & 2.17 & 2.20 & 3.41 & 2.28 & 1.29 \\
\hline \multicolumn{14}{|c|}{ B. Performance [\% p.m.] } \\
\hline MER (equal-weighted) & $0.1308 *$ & $0.1567 * *$ & $0.1153 *$ & $0.1596 * * *$ & 0.0922 & $0.1694 *$ & 0.4072 & 0.3647 & 0.3334 & 0.3530 & 0.5165 & 0.5602 & $-0.0272 * * *$ \\
\hline MER (value-weighted) & $0.1544 * *$ & $0.1938 * *$ & 0.1351 ** & $0.1830 * * *$ & 0.1039 & $0.2249 * *$ & 0.3834 & 0.4341 & 0.3610 & 0.3829 & 0.5240 & 0.5206 & $-0.0071 * * *$ \\
\hline \multirow{2}{*}{ Alpha (equal-weighted) } & $-0.0644 * * *$ & $-0.0515 * * *$ & $-0.0741 * * *$ & $-0.0377 * *$ & $-0.0713 * * *$ & $-0.0866 *$ & $-0.0978 * *$ & -0.1041 & $-0.1064 * * *$ & -0.0722 & -0.1171 & -0.0581 & 0.0031 \\
\hline & $\{97.28\}$ & $\{96.00\}$ & $\{98.29\}$ & $\{93.05\}$ & $\{96.92\}$ & $\{84.18\}$ & $\{97.92\}$ & $\{94.78\}$ & $\{98.75\}$ & $\{97.71\}$ & $\{93.41\}$ & $\{94.99\}$ & $\{32.95\}$ \\
\hline \multirow{2}{*}{ Alpha (value-weighted) } & $-0.0620 * * *$ & \multirow{2}{*}{$-0.0424\{91.38\}$} & $-0.0620 * * *$ & $-0.0396 * * *$ & $-0.0638 * * *$ & -0.0514 & $-0.0804 * * *$ & -0.0353 & -0.0759 & -0.1160 & -0.1618 ** & -0.0360 & 0.0074 \\
\hline & $\{96.16\}$ & & $\{98.56\}$ & $\{96.82\}$ & $\{96.33\}$ & $\{89.25\}$ & $\{98.07\}$ & $\{93.96\}$ & $\{98.25\}$ & $\{97.74\}$ & $\{92.93\}$ & $\{94.49\}$ & $\{24.24\}$ \\
\hline
\end{tabular}

This Table shows summary statistics (Panel I.) and performance measures (Panel II.) for fund groups representing different asset classes. Size is denoted in Mio US\$ and represents the time series mean of the monthly total net assets (TNA) of the fund group. Total volume in December 2009 is denoted in Mio US\$ and represents the accumulated TNA of all funds of a fund group at the end of the data sample. Expense ratios are denoted in \% p.a. and represent the equal-weighted (value-weighted) time series mean of the fund group. Age is denoted in months since the first return observation and represents the time series mean of the fund group. Absolute (relative) flows are denoted in Mio US\$ p.m. (\% p.m.) and represent the time series mean of the fund group. MER is denoted in \% p.m. and represents the time series mean of the fund group. Alpha is denoted in \% p.m. and represents the intercept of a multi-factor regression. *, **, *** indicates statistical significance on the $1 \%$, $5 \%$, and $10 \%$ level based upon HAC-consistent covariances (Newey and West [54]). Adjusted $\mathrm{R}^{2}$ statistics are shown in curly brackets and denoted in \%. 
Money market funds show the highest absolute flows but—due to their size-relatively low relative flows. Equity funds show higher absolute and relative flows than bond funds. Mortgage-backed bond funds even show negative absolute flows during the sample period and very low but positive relative flows. This indicates that large funds average high absolute but low relative outflows, while small funds usually have low absolute but high relative inflows. ${ }^{4}$ General bond funds have the highest flows among bond funds. Among equity funds absolute and relative flows are more or less evenly distributed. Panel B shows performance measures for equal-weighted and value-weighted fund portfolios. In terms of the risk-unadjusted MER, equity funds show higher performance than bond funds while money market funds even show significant and negative MER. The value-weighted portfolios outperform their equal-weighted counterparts, meaning that larger funds earn higher returns, on average, than smaller funds. As an exception, smaller small-cap funds usually seem to outperform larger small-cap funds because here the equal-weighted portfolio has the higher MER.

In terms of the risk-adjusted multi-factor alphas, the relation is the other way around. Here, the measures for all fund groups are negative, in most cases significantly, except for money market funds, where I find positive, if insignificant, performance. However, the $\mathrm{R}^{2}$ statistics in curly brackets \} for bond funds and equity funds are above $90 \%$ for almost all fund groups while they are 33\% and $24 \%$ for equal-weighted and value-weighted money market funds, respectively, so that one cannot directly compare these alphas. In addition, equal-weighted bond funds show higher alphas than equal-weighted equity funds, while value-weighted aggressive growth and small cap funds show the highest performance among bond and equity funds. Apart from this, the other value-weighted equity fund groups underperform all bond funds groups. Again, value-weighted portfolios outperform equalweighted portfolios in most cases except growth/income and mid-cap funds.

Among bond funds, I expect mortgage-backed bond funds to play a special role as these show negative flows and are comparatively large. In addition, general and corporate bond funds show very high flows compared to other bond funds. Most equity fund groups show similar relative flows except for mid-cap funds, which might play a special role. Despite money market funds showing very high absolute inflows, I do not expect to find significant results because return and return variability are very low.

\section{Empirical Analysis}

\subsection{The Size-Performance Relation}

Fund flows are strongly related to fund size. Therefore, in Table 3 I report the performance as well as absolute and relative flows for value-weighted deciles ranked by TNA lagged one month and grouped into bond funds, equity funds, and money market funds (e.g., Chen et al. [27]). ${ }^{5}$ In addition, the table shows performance differences between the smallest (decile 1) and the largest funds (decile 10),

4 Consider two funds A and B. A has an absolute flow of -2 (outflow), whereas B has an absolute flow of +1 (inflow). The average absolute flow is -1 . Now consider A's size was 20 before the flow, so the relative flow is $-10 \%$. B's size was 8 , so the relative flow is $+12.5 \%$. Average relative flow is $+2.5 \%$.

5 As TNA shows high autocorrelation; I do not report statistics for size-deciles ranked upon TNA with time lags greater than one month. 
between the smallest $30 \%$ and the largest $30 \%$, where, e.g., the smallest $30 \%$ is an equal-weighted portfolio of deciles 1, 2, and 3, and between the middle $40 \%$ and the outer $60 \%$.

In terms of fund flows, the table shows very clear relations throughout all fund groups. For relative flows, small funds experience the highest inflows, whereas the largest funds have the lowest inflows. For absolute flows it is the other way round, as here the smallest funds have the lowest inflows and the largest funds have the highest inflows. Not reported in the table due to space limitations, these relations are monotonic throughout all deciles. I find the highest relative inflows for the smallest equity funds, and the highest absolute inflows for the largest bond funds, closely followed by the largest money market funds.

As to size-decile performance, the table shows different relations, depending on the fund group. In the case of bond funds, smaller funds underperform larger funds, measured significantly by MER. The same holds for money market funds, where I find significant performance differences for both performance measures. The alpha of decile 10 is even positive, if insignificant. These results clearly show a positive correlation between fund size and performance. For equity funds the table reports mixed results, as here the largest $10 \%$ outperforms the smallest $10 \%$, though it is the reverse for the $30 \%$ portfolios.

Table 3. Performance of deciles ranked by fund size.

\begin{tabular}{cccc}
\hline & Bond Funds & Equity Funds & Money Market Funds \\
\hline & Monthly mean excess return $($ MER) & \\
\hline Decile 1 (small) & 0.0884 & 0.3522 & $-0.0687 * * *$ \\
Decile 10 (large) & $0.1607 * *$ & 0.3809 & -0.0008 \\
Largest - smallest & $0.0723 * * *$ & 0.0287 & $0.0679 * * *$ \\
Larger 30\% - smaller 30\% & $0.0333 *$ & -0.0168 & $0.0464 * * *$ \\
Middle 40\% - outer 60\% & 0.0016 & 0.0285 & $0.0026 * * *$ \\
\hline & Monthly multi-factor alpha & $-0.0212 * *$ \\
\hline Decile 1 (small) & $-0.1000 * * *$ & $-0.1099 *$ & 0.0083 \\
Decile 10 (large) & $-0.0660 * * *$ & $-0.0696 * *$ & $0.0295 * * *$ \\
Largest - smallest & 0.0341 & 0.0403 & $0.0185 * * *$ \\
Larger 30\% - smaller 30\% & 0.0116 & -0.0302 & -0.0008 \\
Middle 40\% - outer 60\% & 0.0140 & -0.0128 & \\
\hline & Relative [absolute] fund flows & 3.02 \\
\hline & 3.08 & 6.05 & {$[1.83]$} \\
Decile 1 (small) & {$[0.51]$} & {$[0.32]$} & 0.48 \\
& 0.21 & 0.36 & {$[101.54]$} \\
\hline
\end{tabular}

This table shows performance measures and performance differences as well as fund flows for decile portfolios ranked by beginning-of-month TNA. MER and alpha are denoted in \% p.m. *, **, *** indicates statistical significance on the 1\%, 5\%, and 10\% level based upon HAC-consistent covariances (Newey and West [54]). Relative flows are denoted in \% p.m. Absolute flows are reported in square brackets and denoted in Mio US\$ p.m. The table shows performance differences between the largest (decile 10) and the smallest funds (decile 1), between the larger 30\% and the smaller 30\% where, e.g., "smaller 30\%" is an equalweighted portfolio of deciles 1,2 , and 3 , and between the middle $40 \%$ and the outer $60 \%$. Due to space 
limitations the table only shows performance measures and flows on the largest and the smallest deciles.

Measures for all other deciles are available on request.

These results clearly show that fund flows are generally and consistently related to fund size, positively with absolute flows and negatively with relative flows. In addition, performance is positively related to size for bond funds and money market funds. For equity funds the relationship is not as strong but existent in the extreme portfolios. Therefore, I expect fund returns to be related to fund flows, especially for specific bond fund objectives.

\subsection{Performance Persistence}

Another issue in the relation between fund flows and future returns is performance persistence. It is clearly established that flows chase performance such that in periods following superior returns fund flows should be high and in periods following inferior returns fund flows should be low, if not negative (e.g., Ippolito [7]; Ivković and Weisbenner [2]). This is only beneficial if performance persists (e.g., Hendriks et al. [38]; Brown and Goetzmann [52]; Carhart [47]). Table 4 gives a first indication of the validity of this relation by showing correlation coefficients between fund portfolio returns and future flows. For bond funds and equity funds, the table clearly confirms the relation as future absolute and relative flows are positively correlated with returns while correlation coefficients decrease with increasing time lag. The table shows unexpected relations for money market funds. While absolute flows leading 1, 2, (and 3) months are positively correlated as expected, relative flows and absolute flows leading by more than 3 months are highly negatively correlated-meaning that superior returns are followed by relative outflows rather than by increased inflows. However, as money market funds have very low returns on average, with very low return variability, these correlations might not be too meaningful.

Table 4. Correlation coefficients between returns and future flows.

\begin{tabular}{|c|c|c|c|c|c|c|}
\hline & \multicolumn{2}{|c|}{ Bond Fund Returns } & \multicolumn{2}{|c|}{ Equity Fund Returns } & \multicolumn{2}{|c|}{ Money Market Fund Returns } \\
\hline & Equal-Weighted & Value-Weighted & Equal-Weighted & Value-Weighted & Equal-Weighted & Value-Weighted \\
\hline \multicolumn{7}{|c|}{ Future absolute flows } \\
\hline$(t+1 m)$ & 40.91 & 42.54 & 37.62 & 37.79 & 12.48 & 26.55 \\
\hline$(t+2 m)$ & 22.49 & 23.34 & 27.34 & 26.05 & 2.76 & 17.56 \\
\hline$(t+3 m)$ & 14.95 & 15.21 & 13.41 & 14.92 & -1.44 & 10.87 \\
\hline$(t+4 m)$ & 10.16 & 11.06 & 28.55 & 29.55 & -13.91 & -2.47 \\
\hline$(t+5 m)$ & 9.37 & 9.00 & 21.84 & 21.54 & -12.83 & -5.05 \\
\hline$(t+6 m)$ & 5.33 & 4.48 & 8.92 & 10.28 & -16.36 & -5.52 \\
\hline \multicolumn{7}{|c|}{ Future relative flows } \\
\hline$(t+1 m)$ & 31.38 & 30.11 & 24.05 & 22.57 & -10.79 & 2.46 \\
\hline$(t+2 m)$ & 28.88 & 27.86 & 18.52 & 17.42 & -8.77 & 3.49 \\
\hline$(t+3 m)$ & 22.44 & 20.94 & 7.90 & 9.41 & -14.54 & -3.71 \\
\hline$(t+4 m)$ & 17.86 & 16.59 & 11.71 & 12.28 & -16.62 & -8.75 \\
\hline$(t+5 m)$ & 16.44 & 13.96 & 18.37 & 18.06 & -28.06 & -21.57 \\
\hline$(t+6 m)$ & 19.95 & 18.32 & 7.58 & 7.96 & -21.02 & -12.94 \\
\hline
\end{tabular}

This table shows correlation coefficients between equal-weighted and value-weighted fund portfolio returns and future absolute and relative fund flows to the same portfolios in the period from January 1993 through 
December 2009 for bond funds, equity funds, and money market funds. " $m$ " stands for "month" so that $(t+1 m)$ represents future fund flows leading by 1 month, $(t+2 m)$ by 2 months, etc. Correlation coefficients are denoted in \%.

Following the liquidity cost argument from the literature (e.g., Edelen [26]; Rakowski [34]), high fund flows should erode fund returns because funds are likely to face problems in allocating their new money advantageously. This means that, if flows follow superior performance which Table 4 confirms for bond funds and equity funds, there should be no performance persistence. However, for money market funds, where correlations in Table 4 are low or negative, I expect to find at least some evidence for performance persistence. To test for performance persistence Table 5 shows performance measures and flows for decile portfolios ranked by past returns as well as performance differences between the deciles, or zero-investment portfolios based upon the deciles, respectively. ${ }^{6}$ Panel A shows results for deciles ranked by returns lagged one month $(t-1 \mathrm{~m})$. In the lower part the table, negative flows follow low performance and positive flows follow high performance, as expected.

Table 5. Performance of deciles ranked by lagged return.

\begin{tabular}{|c|c|c|c|c|c|c|}
\hline & Bond Funds & $\begin{array}{l}\text { Equity } \\
\text { Funds }\end{array}$ & $\begin{array}{c}\text { Money } \\
\text { Market } \\
\text { Funds }\end{array}$ & $\begin{array}{l}\text { Bond } \\
\text { Funds }\end{array}$ & $\begin{array}{l}\text { Equity } \\
\text { Funds }\end{array}$ & $\begin{array}{c}\text { Money } \\
\text { Market } \\
\text { Funds }\end{array}$ \\
\hline & \multicolumn{3}{|c|}{ A. Ranked by Monthly Return $(t-1 \mathrm{~m})$} & \multicolumn{3}{|c|}{ B. Ranked by monthly return $(t-2 m)$} \\
\hline \multicolumn{7}{|c|}{ Monthly mean excess return (MER) } \\
\hline Decile 1 (lowest) & -0.1652 & -0.0720 & $-0.1038 * * *$ & 0.1185 & 0.1929 & $-0.1077 * * *$ \\
\hline Decile 10 (highest) & $0.3692 * * *$ & $0.8043 * *$ & $0.0235 * * *$ & 0.1697 & 0.5728 & $0.0257 * * *$ \\
\hline Highest - lowest & $0.5343 * * *$ & $0.8763 * * *$ & $0.1273 * * *$ & 0.0511 & 0.3799 & $0.1334 * * *$ \\
\hline Higher 30\% - lower 30\% & $0.3183 * * *$ & $0.5103 * *$ & $0.0963 * * *$ & 0.0498 & 0.1889 & $0.0984 * * *$ \\
\hline Middle $40 \%$ - outer $60 \%$ & 0.0393 & -0.0259 & $0.0202 * * *$ & 0.0179 & -0.0213 & $0.0202 * * *$ \\
\hline \multicolumn{7}{|c|}{ Monthly multi-factor alpha } \\
\hline Decile 1 (lowest) & $-0.4576 * * *$ & $-0.5638 * * *$ & -0.0087 & -0.1140 & -0.1520 & -0.0054 \\
\hline Decile 10 (highest) & $0.1655 *$ & $0.2580 *$ & $0.0337 * * *$ & -0.0979 & -0.0488 & $0.0298 * * *$ \\
\hline Highest - lowest & $0.6231 * * *$ & $0.8218 * * *$ & $0.0425 * * *$ & 0.0161 & 0.1032 & $0.0352 * * *$ \\
\hline Higher 30\% - lower 30\% & $0.3655 * * *$ & $0.4625 * * *$ & $0.0330 * * *$ & 0.0337 & 0.0120 & $0.0297 * * *$ \\
\hline Middle $40 \%$ - outer $60 \%$ & $0.0668 * *$ & 0.0189 & $-0.0129 * * *$ & 0.0145 & 0.0117 & $-0.0129 * * *$ \\
\hline \multicolumn{7}{|c|}{ Relative [absolute] fund flows } \\
\hline Deci & -0.39 & -0.31 & 0.07 & -0.36 & -0.21 & 0.06 \\
\hline Decile 1 (Iowest) & {$[-5.14]$} & {$[-14.71]$} & {$[-1.26]$} & {$[-7.92]$} & {$[-17.07]$} & {$[-29.37]$} \\
\hline Decile 10 h & 0.30 & 1.52 & 1.36 & 0.24 & 1.27 & 1.22 \\
\hline Decile 10 (nignest) & [31.70] & [55.34] & [156.64] & [39.35] & [51.22] & [65.18] \\
\hline
\end{tabular}

6 Note that this way of testing performance persistence potentially suffers from survivorship bias or look-ahead bias because inferiorly performing funds might disappear between the ranking period and the evaluation period causing positive selection (e.g., ter Horst et al. [42,43]). However, this is mostly a problem for longer time lags; thus that finding significant performance persistence over longer horizons should be treated with caution. 
Table 5. Cont.

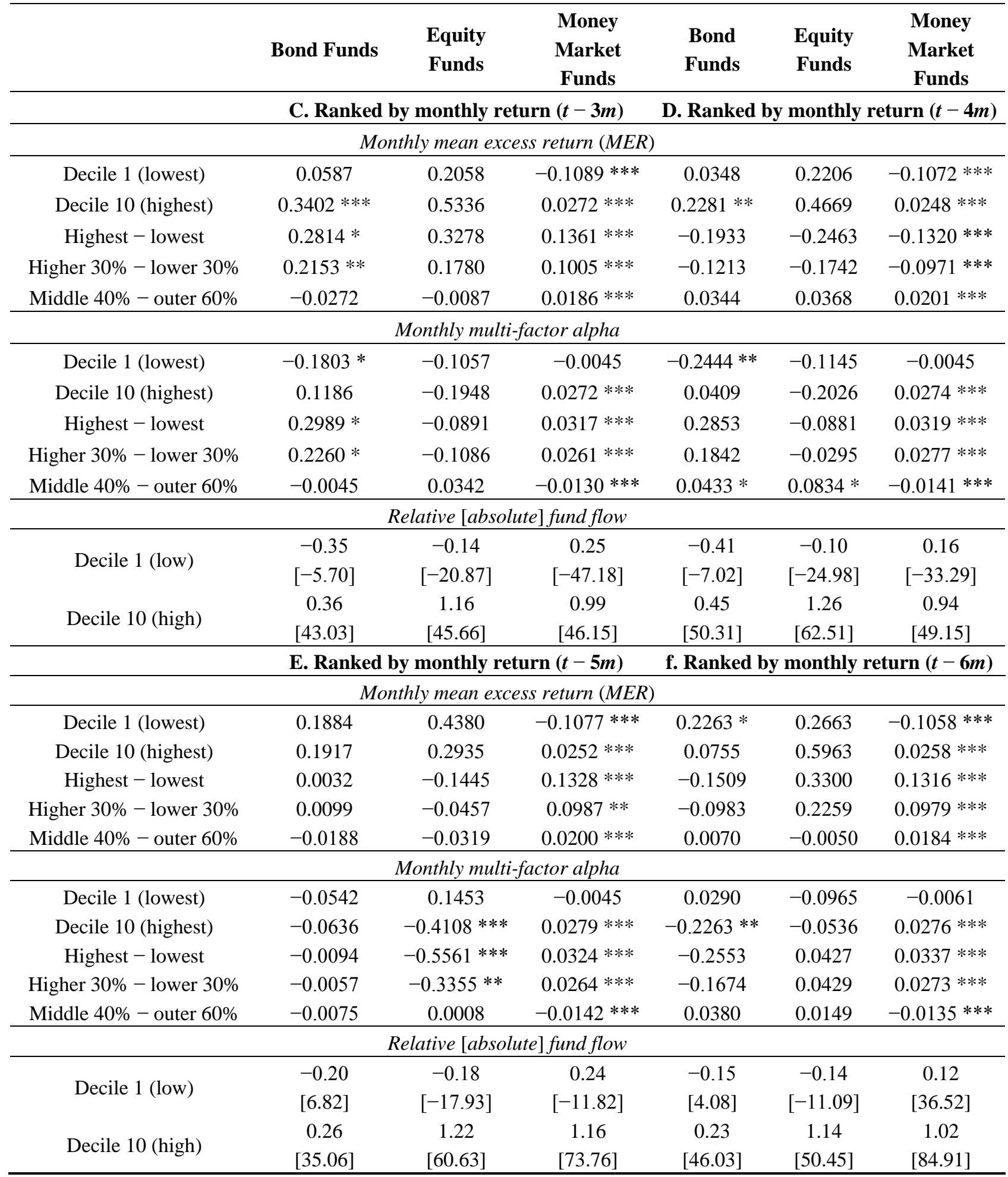

This table shows performance and fund flows of decile portfolios ranked by lagged monthly return (Panels I-VI). MER and alpha are denoted in \% p.m. *, **, *** indicates statistical significance on the $1 \%, 5 \%$, and $10 \%$ level based upon HAC-consistent covariances (Newey and West [54]). Relative flows are denoted in \% p.m. Absolute flows are reported in square brackets and denoted in Mio US\$ p.m. The table shows performance differences between the highest and the lowest performance deciles, between the higher $30 \%$ and the lower $30 \%$ where, e.g., "lower $30 \%$ " is an equal-weighted portfolio of deciles 1 , 2, and 3 , and between the middle $40 \%$ and the outer $60 \%$. Due to space limitations the table only shows performance 
measures and flows for the highest and the lowest return deciles. Measures for all other deciles are available on request.

Concerning performance, Panel A shows a clear performance persistence structure, with decile 1 shows the lowest performance, and decile 10 the highest. In addition, I find a positive and significant performance by decile 10, even on a risk-adjusted basis, as well as significant and positive returns to both zero-investment "highest - lowest" and "higher 30\% - lower 30\%" portfolios for all three fund groups. This is in line with the short-term persistence findings by, among others, Bollen and Busse [55].

Panel B of Table 5 shows results for deciles ranked by returns lagged two months $(t-2 m)$. Consistent with Table 4, decile 1 experiences outflows while decile 10 experiences inflows for all the fund groups. As for performance, I find significant and positive returns for the zero-investment portfolios as well as positive and significant performance in decile 10 only for money market funds. Consistent with Berk and Green [21], this is not the case for bond funds and equity funds.

Panels $\mathrm{C}$ and $\mathrm{D}$ show results for deciles ranked by returns lagged three and four months, respectively. In the lower part, flows show the same structure as in the panels before. As to performance, I find clear evidence for significantly persistent money market fund performance with significantly positive alphas for decile 10. Surprisingly, I also find significant and positive performance persistence for bond funds. For equity funds, neither panels shows any evidence of performance persistence.

Panels E and F show results for deciles ranked by returns lagged five and six months, respectively. Especially in Panel F the table shows positive flows also for decile 1 of bond funds and money market funds. Concerning performance persistence, I find evidence for significant and positive returns to the zero-investment portfolios and positive performance for decile 10 for money market funds. Notably, the performance of the zero-investment portfolios is more or less constant over all six panels. For equity funds, Panel E shows a significant performance reversal on a risk-adjusted basis, but no significant results for bond funds. Panel F shows no noteworthy results for equity or bond funds.

From this, I expect to find significant relations between past flows and future returns for bond funds but not for equity funds in the next section, especially for short horizons. Even though money market funds show significant performance persistence, the correlations with past flows are very low or even negative (Table 4). Thus, I do not expect significant results for money market funds.

\subsection{The Flow-Performance Relation}

In previous sections I show that there are positive correlations between fund returns and future fund flows, confirming that investors partly ground investment decisions upon past returns. In addition, I show performance persistence in bond fund and money market fund performance. As a consequence, I expect fund flows to have at least some information content relevant to future returns. Such findings would be consistent with mutual fund managers using inflows to buy past winner funds (momentum) which in turn causes fund returns to persist over the short horizons (Grinblatt and Titman [36,37]). To test for the validity of this expectation, Table 6 shows the performance of decile portfolios ranked by past relative flows as well as performance differences between the highest and the lowest deciles, 
between the higher $30 \%$ and the lower $30 \%$, and between the middle $40 \%$ and the outer $60 \%$. ${ }^{7}$ Panel A of Table 6 shows results of flow-deciles ranked by relative flows lagged one month. As a first finding, all fund groups show positive "highest - lowest" and "higher 30\% - lower 30\%" differences, respectively, showing that funds with high past flows outperform funds with low past flows. This is particularly pronounced for bond funds, where most results are statistically significant except for government bond funds. Money market funds show significant but very small outperformance of high past flow deciles for MER but not for alpha. As for equity funds, only small-cap funds show statistically significant differences, while all other groups are insignificant. This pattern in small-cap equity funds could be related to particularly strong momentum patterns of small stocks documented by, e.g., Fama and French [56]. ${ }^{8}$

7 Due to space limitations the table only shows performance measures for the extreme deciles.

8 Among others, Avramov and Chordia [57] have shown that the "traditional” return momentum factor by Carhart [47] does not capture all momentum. Therefore, e.g., Huehn and Scholz [58] introduce other sorts of momentum, such as factor-related momentum and idiosyncratic (alpha) momentum. 
Table 6. Deciles ranked by relative flows.

\begin{tabular}{|c|c|c|c|c|c|c|c|c|c|c|c|c|c|}
\hline & \multicolumn{6}{|c|}{ Bond Funds } & \multicolumn{6}{|c|}{ Equity funds } & \multirow{2}{*}{$\begin{array}{c}\text { Money } \\
\text { Market } \\
\text { Funds }\end{array}$} \\
\hline & All & Corporate & $\begin{array}{c}\text { Govern- } \\
\text { ment } \\
\end{array}$ & $\begin{array}{c}\text { Mortgage- } \\
\text { Backed } \\
\end{array}$ & Municipal & General & All & $\begin{array}{c}\text { Aggressive } \\
\text { Growth }\end{array}$ & Growth & $\begin{array}{l}\text { Growth/ } \\
\text { Income }\end{array}$ & Mid-Cap & Small-Cap & \\
\hline \multicolumn{14}{|c|}{ A. Ranking by monthly relative flows lagged 1 month $(t-1 \mathrm{~m})$} \\
\hline \multicolumn{14}{|c|}{ Monthly mean excess return (MER) } \\
\hline Decile 1 (lowest) & 0.0176 & 0.0363 & 0.1005 & 0.0019 & -0.0380 & 0.0367 & 0.2546 & 0.3275 & 0.1996 & 0.2429 & 0.5724 & 0.3242 & 0.0004 \\
\hline Decile 10 (highest) & $0.2191 * * *$ & $0.2518 * * *$ & $0.1399 *$ & $0.2300 * * *$ & $0.1161 *$ & $0.2894 * * *$ & 0.4333 & 0.5157 & 0.3441 & 0.3715 & $0.8162 * *$ & $0.7938 * *$ & $0.0043 *$ \\
\hline Highest - lowest & $0.2015 * * *$ & $0.2155^{* * *}$ & 0.0394 & $0.2281 * * *$ & $0.1541 * *$ & $0.2528 * *$ & 0.1787 & 0.1882 & 0.1444 & 0.1286 & 0.2438 & $0.4695 * * *$ & $0.0039 * *$ \\
\hline Higher 30\% - lower 30\% & $0.1502 * * *$ & $0.1395^{* * *}$ & 0.0297 & $0.1346 * * *$ & $0.0932 * *$ & $0.1794 * * *$ & 0.2122 & 0.1484 & 0.1656 & $0.1432 *$ & 0.2209 & $0.3542 * * *$ & $0.0046 * * *$ \\
\hline Middle $40 \%$ - outer $60 \%$ & 0.0273 & 0.0504 & -0.0051 & $0.0394 * *$ & 0.0535 *** & 0.0322 & 0.0086 & 0.0421 & 0.0509 & 0.0239 & $-0.1284 * * *$ & -0.0100 & $-0.0080 * * *$ \\
\hline \multicolumn{14}{|c|}{ Monthly multi-factor alpha } \\
\hline Decile 1 (lowest) & $-0.1810 * * *$ & $-0.1433 * *$ & -0.0504 & $-0.1343 *$ & $-0.2106 * * *$ & $-0.2432 * *$ & $-0.1433 *$ & -0.1439 & -0.1156 & $-0.1400 *$ & 0.0050 & $-0.3391 * * *$ & 0.0066 \\
\hline Decile 10 (highest) & 0.0377 & 0.0691 & -0.0460 & 0.0205 & -0.0154 & 0.0428 & -0.1190 & -0.1089 & -0.0739 & $-0.1012 * *$ & 0.1211 & 0.0469 & $0.0100 *$ \\
\hline Highest - lowest & $0.2186 * * *$ & $0.2124 * * *$ & 0.0044 & $0.1548 * *$ & $0.1952 * *$ & $0.2860 *$ & 0.0244 & 0.0350 & 0.0416 & 0.0388 & 0.1161 & $0.3860 * * *$ & 0.0034 \\
\hline Higher $30 \%$ - lower $30 \%$ & $0.1689 * * *$ & $0.1525 * * *$ & 0.0168 & $0.0877^{* *}$ & $0.1179 * *$ & $0.1978 * * *$ & 0.0713 & 0.0706 & 0.0746 & 0.0792 & 0.0891 & $0.2213 * *$ & 0.0032 \\
\hline Middle $40 \%$ - outer $60 \%$ & 0.0162 & 0.0029 & -0.0189 & 0.0124 & $0.0480 * * *$ & 0.0213 & 0.0208 & 0.0514 & 0.0341 & 0.0130 & $-0.1362 * * *$ & -0.0118 & $-0.0035 *$ \\
\hline \multicolumn{14}{|c|}{ B. Ranking by monthly relative flows lagged 2 month $(t-2 m)$} \\
\hline \multicolumn{14}{|c|}{ Monthly mean excess return (MER) } \\
\hline Decile 1 (lowest) & 0.1050 & 0.1596 & 0.1149 & 0.0034 & -0.0186 & -0.0248 & 0.4881 & 0.4913 & 0.4501 & 0.4829 & $0.6854 *$ & 0.5566 & -0.0012 \\
\hline Decile 10 (highest) & $0.2079 * * *$ & $0.2212 * *$ & $0.1595 * *$ & $0.2649 * * *$ & 0.1061 & $0.3154 * * *$ & 0.5368 & 0.3619 & 0.5754 & $0.5010 *$ & $0.7564 *$ & $0.8022 *$ & 0.0022 \\
\hline Highest - lowest & 0.1029 & 0.0616 & 0.0446 & $0.2614 * * *$ & $0.1247 *$ & $0.3402 * * *$ & 0.0487 & -0.1294 & 0.1253 & 0.0181 & 0.0710 & $0.2456 *$ & $0.0034 *$ \\
\hline Higher 30\% - lower 30\% & 0.0547 & 0.0283 & 0.0175 & $0.1370 * * *$ & 0.0557 & $0.2089 * * *$ & 0.0322 & -0.0530 & 0.0239 & 0.0905 & 0.1548 & 0.1880 & $0.0041 * * *$ \\
\hline Middle $40 \%$ - outer $60 \%$ & -0.0046 & 0.0047 & 0.0034 & 0.0139 & $0.0426 * * *$ & 0.0460 & 0.0280 & 0.0233 & 0.0536 & -0.0054 & -0.0521 & -0.0182 & $-0.0149 * * *$ \\
\hline \multicolumn{14}{|c|}{ Monthly multi-factor alpha } \\
\hline Decile 1 (lowest) & $-0.0949 *$ & -0.0694 & -0.0544 & $-0.1601 * * *$ & $-0.1723 * *$ & $-0.3170 * * *$ & -0.1360 & -0.0023 & -0.1357 & 0.0951 & -0.0308 & $-0.2368 * *$ & 0.0045 \\
\hline Decile 10 (highest) & -0.0019 & 0.0170 & -0.0207 & 0.0532 & -0.0421 & 0.0433 & -0.0729 & -0.2952 & 0.0514 & $-0.0725 *$ & 0.0437 & -0.0223 & 0.0079 \\
\hline Highest - lowest & 0.0930 & 0.0865 & 0.0337 & $0.2133 * * *$ & $0.1303 *$ & $0.3603 * * *$ & 0.0632 & -0.2929 & 0.1871 & 0.0226 & 0.0745 & 0.2145 & 0.0035 \\
\hline Higher $30 \%$ - lower $30 \%$ & 0.0625 & 0.0437 & 0.0182 & $0.1068 * * *$ & 0.0774 & $0.1966 * * *$ & 0.0037 & -0.0965 & 0.0405 & 0.0769 & 0.1179 & 0.1604 & 0.0020 \\
\hline Middle $40 \%$ - outer $60 \%$ & -0.0202 & -0.0214 & -0.0042 & -0.0024 & $0.0223 *$ & 0.0188 & 0.0524 & -0.0489 & 0.0581 & 0.0109 & -0.0575 & 0.0115 & $-0.0104 * * *$ \\
\hline
\end{tabular}


Table 6. Cont

\begin{tabular}{|c|c|c|c|c|c|c|c|c|c|c|c|c|c|}
\hline & \multicolumn{6}{|c|}{ Bond Funds } & \multicolumn{6}{|c|}{ Equity funds } & \multirow{2}{*}{$\begin{array}{c}\text { Money } \\
\text { Market } \\
\text { Funds } \\
\end{array}$} \\
\hline & All & Corporate & $\begin{array}{c}\text { Govern- } \\
\text { ment } \\
\end{array}$ & $\begin{array}{c}\text { Mortgage- } \\
\text { Backed }\end{array}$ & Municipal & General & All & $\begin{array}{c}\text { Aggressive } \\
\text { Growth } \\
\end{array}$ & Growth & $\begin{array}{l}\text { Growth/ } \\
\text { Income }\end{array}$ & Mid-Cap & Small-cap & \\
\hline \multicolumn{14}{|c|}{ C. Ranking by monthly relative flows lagged 3 month $(t-3 m)$} \\
\hline \multicolumn{14}{|c|}{ Monthly mean excess return (MER) } \\
\hline Decile 1 (lowest) & 0.0809 & 0.1214 & $0.1266 *$ & 0.0444 & -0.0251 & 0.0953 & 0.3424 & $0.7466 * *$ & 0.1701 & 0.3669 & 0.3693 & 0.5681 & -0.0005 \\
\hline Decile 10 (highest) & $0.1830 * * *$ & $0.2052 * * *$ & 0.0799 & $0.2255^{* * *}$ & 0.0878 & $0.1914 *$ & 0.4981 & 0.3003 & 0.3578 & 0.3556 & $0.7429 *$ & $0.7493 *$ & 0.0029 \\
\hline Highest - lowest & $0.1020 *$ & 0.0838 & -0.0467 & $0.1812 * * *$ & $0.1129 * *$ & 0.1146 & 0.1557 & -0.4463 & 0.1877 & -0.0114 & $0.0374 *$ & 0.1813 & $0.0034 * *$ \\
\hline Higher 30\% - lower 30\% & $0.0906 *$ & 0.0710 & 0.0182 & $0.0854 * * *$ & 0.0553 & 0.0975 & 0.0979 & -0.1415 & 0.0945 & 0.0501 & $0.2376 *$ & 0.1322 & $0.0052 * * *$ \\
\hline Middle $40 \%$ - outer $60 \%$ & -0.0084 & -0.00186 & 0.0199 & 0.0124 & $0.0422 * *$ & 0.0512 & 0.0005 & -0.0178 & 0.0650 ** & 0.0153 & -0.0199 & -0.0104 & $-0.0149 * * *$ \\
\hline \multicolumn{14}{|c|}{ Monthly multi-factor alpha } \\
\hline Decile 1 (lowest) & $-0.1117 * * *$ & -0.0649 & -0.0533 & -0.0997 & $-0.1714 * * *$ & $-0.1904 * * *$ & 0.1098 & 0.2485 & $-0.1977 *$ & -0.0215 & -0.1948 & -0.1697 & 0.0104 \\
\hline Decile 10 (highest) & -0.0031 & -0.0046 & $-0.0974 *$ & 0.0226 & $-0.0645 * *$ & -0.0256 & -0.0774 & $-0.3887 *$ & -0.0972 & $-0.0935 * *$ & 0.0651 & -0.0469 & 0.0085 \\
\hline Highest - lowest & $0.1085 * *$ & 0.0603 & -0.0441 & $0.1223 *$ & $0.1069 *$ & $0.1679 *$ & 0.0324 & $-0.6372 * *$ & 0.1006 & -0.0720 & 0.2598 & 0.1228 & -0.0019 \\
\hline Higher 30\% - lower 30\% & 0.0915 ** & $0.0707 *$ & 0.0119 & 0.0495 & 0.0600 & $0.1040 * *$ & -0.0167 & -0.2142 & 0.0353 & -0.0004 & 0.1162 & 0.0189 & -0.0012 \\
\hline Middle $40 \%$ - outer $60 \%$ & -0.0240 & -0.0567 & 0.0108 & -0.0088 & $0.0288 * *$ & 0.0257 & 0.0532 & 0.0419 & $0.0688 * *$ & 0.0189 & -0.0324 & 0.0044 & $-0.0088 * * *$ \\
\hline \multicolumn{14}{|c|}{ D. Ranking by monthly relative flows lagged 4 month $(t-4 m)$} \\
\hline \multicolumn{14}{|c|}{ Monthly mean excess return (MER) } \\
\hline Decile 1 (lowest) & 0.1084 & 0.0943 & 0.1192 & $0.1138 * *$ & 0.0312 & 0.1172 & 0.3102 & 0.4478 & 0.1954 & 0.3572 & $0.6688 *$ & 0.5298 & -0.0005 \\
\hline Decile 10 (highest) & $0.2050 * * *$ & $0.2438 * * *$ & 0.1258 & $0.2321 * * *$ & 0.0759 & $0.1886 *$ & 0.3936 & 0.3428 & 0.3113 & 0.3441 & 0.5930 & $0.7633 *$ & 0.0034 \\
\hline Highest - lowest & $0.0966 *$ & $0.1495 * *$ & 0.0067 & $0.1184 * *$ & 0.0447 & 0.0952 & 0.0834 & -0.1050 & 0.1160 & -0.0131 & -0.0758 & $0.2335 *$ & $0.0039 * *$ \\
\hline Higher 30\% - lower 30\% & $0.0864 * *$ & $0.1179 * *$ & -0.0264 & $0.0782 * * *$ & 0.0181 & 0.0737 & 0.0763 & 0.0583 & 0.0499 & 0.0758 & 0.0344 & 0.0614 & $0.0046 * * *$ \\
\hline Middle $40 \%$ - outer $60 \%$ & -0.0083 & 0.0222 & 0.0287 & 0.0218 & $0.0283 *$ & 0.0602 & 0.0129 & 0.0795 & $0.0581 *$ & 0.0232 & -0.0570 & -0.0014 & $-0.0154 * * *$ \\
\hline \multicolumn{14}{|c|}{ Monthly multi-factor alpha } \\
\hline Decile 1 (lowest) & $-0.0933 * *$ & $-0.1135 * *$ & -0.0441 & -0.0189 & $-0.1294 * *$ & -0.1161 & -0.1693 & 0.0224 & $-0.2199 *$ & -0.0808 & 0.0949 & -0.1320 & 0.0093 \\
\hline Decile 10 (highest) & 0.0098 & 0.0420 & -0.0822 & 0.0351 & $-0.0670 * *$ & -0.0191 & $-0.1741 * *$ & -0.2809 & -0.1289 & $-0.0937 * *$ & -0.1146 & -0.0455 & 0.0067 \\
\hline Highest - lowest & $0.1031 *$ & $0.1555 * * *$ & -0.0381 & 0.0541 & 0.0624 & 0.1040 & -0.0048 & -0.3033 & 0.0909 & -0.0129 & -0.2095 & 0.0864 & -0.0027 \\
\hline Higher $30 \%$ - lower $30 \%$ & $0.0973 * * *$ & $0.1337 * * *$ & -0.0315 & 0.0445 & 0.0244 & 0.0806 & 0.0287 & -0.0461 & 0.0457 & 0.0657 & -0.0746 & -0.0607 & -0.0011 \\
\hline Middle $40 \%$ - outer $60 \%$ & -0.0165 & 0.0129 & 0.0192 & -0.0112 & 0.0132 & 0.0449 & 0.0508 & 0.0805 & $0.0572 *$ & 0.0361 & -0.0614 & 0.0036 & $-0.0083 * *$ \\
\hline
\end{tabular}


Table 6. Cont.

\begin{tabular}{|c|c|c|c|c|c|c|c|c|c|c|c|c|c|}
\hline & \multicolumn{6}{|c|}{ Bond Funds } & \multicolumn{6}{|c|}{ Equity funds } & \multirow{2}{*}{$\begin{array}{c}\text { Money } \\
\text { Market } \\
\text { Funds } \\
\end{array}$} \\
\hline & All & Corporate & $\begin{array}{c}\text { Govern- } \\
\text { ment } \\
\end{array}$ & $\begin{array}{c}\text { Mortgage- } \\
\text { Backed }\end{array}$ & Municipal & General & All & $\begin{array}{c}\text { Aggressive } \\
\text { Growth } \\
\end{array}$ & Growth & $\begin{array}{l}\text { Growth/ } \\
\text { Income }\end{array}$ & Mid-Cap & Small-Cap & \\
\hline \multicolumn{14}{|c|}{ E. Ranking by monthly relative flows lagged 5 month $(t-5 m)$} \\
\hline \multicolumn{14}{|c|}{ Monthly mean excess return (MER) } \\
\hline Decile 1 (lowest) & $0.1271 *$ & 0.1184 & $0.1875 * *$ & $0.1100 * *$ & 0.0633 & 0.0601 & 0.9344 & 0.4521 & 0.3688 & 0.2444 & 0.5428 & 0.5058 & 0.0002 \\
\hline Decile 10 (highest) & $0.1836 * *$ & $0.2148 * *$ & $0.1491 *$ & 0.2144 & 0.0986 & $0.1997 *$ & 0.4104 & 0.3182 & 0.3382 & 0.3692 & 0.4303 & 0.5211 & 0.0025 \\
\hline Highest - lowest & 0.0564 & 0.0964 & -0.0383 & $0.1045 *$ & 0.0353 & 0.1555 & 0.0160 & -0.1339 & -0.0306 & 0.1249 & -0.1125 & 0.0153 & 0.0023 \\
\hline Higher 30\% - lower 30\% & 0.0438 & 0.0547 & -0.0205 & $0.0854 * *$ & -0.0178 & $0.1316 * *$ & -0.0043 & -0.1439 & -0.0152 & 0.0784 & 0.0429 & 0.0459 & $0.0048 * * *$ \\
\hline Middle $40 \%$ - outer $60 \%$ & 0.0046 & -0.0191 & -0.0058 & 0.0214 & $0.0266 *$ & $0.0870 * *$ & 0.0028 & 0.1307 & $0.0737 * *$ & 0.0163 & $-0.0979 *$ & 0.0399 & $-0.0150 * * *$ \\
\hline \multicolumn{14}{|c|}{ Monthly multi-factor alpha } \\
\hline Decile 1 (lowest) & -0.0331 & -0.0425 & -0.0034 & -0.0147 & $-0.0869 * *$ & $-0.1868 * *$ & -0.0816 & -0.0910 & -0.0590 & $-0.1785 * *$ & 0.0185 & $-0.2084 * *$ & 0.0083 \\
\hline Decile 10 (highest) & -0.0161 & 0.0003 & -0.0458 & 0.0038 & -0.0383 & -0.0139 & -0.1100 & $-0.2676 *$ & -0.0567 & -0.0560 & -0.1923 & $-0.2469 * *$ & 0.0073 \\
\hline Highest - lowest & 0.0170 & 0.0429 & -0.0423 & 0.0185 & 0.0485 & 0.1726 & -0.0284 & -0.1766 & 0.0022 & 0.1225 & -0.2109 & -0.0386 & -0.0010 \\
\hline Higher 30\% - lower 30\% & 0.0332 & 0.0409 & -0.0298 & 0.0448 & 0.0052 & $0.1110 *$ & -0.0514 & -0.2263 & -0.0091 & 0.0715 & -0.0757 & -0.0270 & -0.0017 \\
\hline Middle $40 \%$ - outer $60 \%$ & -0.0164 & -0.0487 & -0.0149 & -0.0093 & 0.0022 & 0.0379 & 0.0511 & 0.1141 & $0.0826 * *$ & 0.0336 & $-0.1464 * * *$ & 0.0395 & $-0.0084 * *$ \\
\hline \multicolumn{14}{|c|}{ F. Ranking by monthly relative flows lagged 6 month $(t-6 \mathrm{~m})$} \\
\hline \multicolumn{14}{|c|}{ Monthly mean excess return (MER) } \\
\hline Decile 1 (lowest) & 0.0904 & 0.1337 & $0.1746 * *$ & $0.1252 * *$ & 0.0578 & 0.1276 & 0.3912 & $0.7350 * *$ & 0.2887 & 0.3332 & 0.3860 & 0.5021 & -0.0007 \\
\hline Decile 10 (highest) & $0.1735 * * *$ & $0.2239 * * *$ & 0.0606 & $0.2347 * * *$ & 0.0811 & 0.1621 & 0.3664 & 0.5269 & 0.3246 & 0.3580 & $0.7283 *$ & 0.6532 & 0.0025 \\
\hline Highest - lowest & 0.0831 & 0.0902 & -0.1139 & $0.1095 *$ & 0.0233 & 0.0515 & -0.0248 & -0.2083 & 0.0359 & 0.0249 & $0.3423 *$ & 0.1511 & $0.0031 *$ \\
\hline Higher 30\% - lower 30\% & 0.0323 & 0.0405 & -0.0528 & $0.0551 *$ & -0.0308 & $0.1000 *$ & 0.0185 & 0.0508 & 0.0121 & 0.0680 & 0.0768 & 0.0521 & $0.0042 * * *$ \\
\hline Middle $40 \%$ - outer $60 \%$ & 0.0055 & 0.0040 & -0.0011 & 0.0092 & $0.0337 * * *$ & $0.0715 *$ & 0.0047 & -0.0887 & $0.0832 * *$ & 0.0029 & -0.0885 & -0.0358 & $-0.0150 * * *$ \\
\hline
\end{tabular}


Table 6. Cont.

\begin{tabular}{|c|c|c|c|c|c|c|c|c|c|c|c|c|c|}
\hline & \multicolumn{6}{|c|}{ Bond Funds } & \multicolumn{6}{|c|}{ Equity funds } & \multirow{2}{*}{$\begin{array}{c}\text { Money } \\
\text { Market } \\
\text { Funds } \\
\end{array}$} \\
\hline & All & Corporate & $\begin{array}{c}\text { Govern- } \\
\text { ment }\end{array}$ & $\begin{array}{c}\text { Mortgage- } \\
\text { Backed }\end{array}$ & Municipal & General & All & $\begin{array}{c}\text { Aggressive } \\
\text { Growth }\end{array}$ & Growth & $\begin{array}{l}\text { Growth/ } \\
\text { Income }\end{array}$ & Mid-Cap & Small-Cap & \\
\hline \multicolumn{14}{|c|}{ F. Ranking by monthly relative flows lagged 6 month $(t-6 m)$} \\
\hline \multicolumn{14}{|c|}{ Monthly multi-factor alpha } \\
\hline Decile 1 (lowest) & $-0.1098 * *$ & -0.0592 & -0.0083 & -0.0269 & $-0.1261 * *$ & -0.1212 & -0.0802 & 0.2092 & -0.0631 & $-0.1100 *$ & -0.1325 & $-0.2455 * *$ & 0.0075 \\
\hline Decile 10 (highest) & -0.0086 & 0.0266 & $-0.1263 * *$ & 0.0134 & $-0.0551 * *$ & -0.1266 & $-0.1899 * *$ & -0.0737 & -0.1489 & $-0.0644 *$ & 0.0157 & -0.1258 & 0.0073 \\
\hline Highest - lowest & $0.1012 *$ & 0.0858 & -0.1180 & 0.0402 & 0.0711 & -0.0054 & -0.1097 & -0.2829 & -0.0858 & 0.0457 & 0.1482 & 0.1197 & -0.0002 \\
\hline Higher $30 \%$ - lower $30 \%$ & 0.0332 & 0.0388 & -0.0652 & 0.0270 & 0.0053 & 0.0838 & -0.0303 & 0.0159 & -0.0185 & 0.0661 & -0.0000 & 0.0253 & -0.0002 \\
\hline Middle $40 \%$ - outer $60 \%$ & -0.0119 & -0.0327 & -0.0004 & -0.0205 & $0.0302 * *$ & 0.0348 & $0.0671 * *$ & -0.0917 & $0.1036 * * *$ & 0.0269 & -0.0684 & 0.0313 & $-0.0064 *$ \\
\hline
\end{tabular}

This table shows performance measures and performance differences for decile portfolios ranked by lagged relative flows. MER and alpha are denoted in \% p.m. *, **, *** indicates statistical significance on the 1\%, 5\%, and 10\% level based upon HAC-consistent covariances (Newey and West [54]). The table shows performance differences between the funds with the highest flows and those with the lowest flows, between the higher $30 \%$ and the lower $30 \%$ where, e.g., "lower $30 \%$ " is an equal-weighted portfolio of deciles 1, 2, and 3, and between the middle $40 \%$ and the outer $60 \%$. Due to space limitations the table only shows performance measures for the extreme deciles. Measures for all other deciles are available on request. 
Interestingly, Panel A shows significant outperformance by the outer deciles over the middle deciles of mid-cap funds, which is in sharp contrast to the hypothesis that extreme inflows or outflows force managers to invest or disinvest inefficiently, respectively, while moderate flows allow optimal investment decisions. Evidence in favor of this hypothesis is shown for municipal bond funds.

Panel B shows results for flow-deciles ranked by relative flow lagged two months. Here, the evidence in general weakens, as can be expected, but still I find significant outperformance of high past flow deciles over low past flow deciles for mortgage-backed and general bond funds. In addition, I find significant outperformance of middle deciles over outer deciles for municipal bond funds and for growth funds. But in general, there is no relevant information content regarding equity fund returns or money market fund returns.

Panels C and D show results for flow-deciles ranked by relative flow lagged three and four months, respectively. Again, I find significant outperformance for high past flow mortgage-backed and general bond funds. In addition, I find evidence for outperformance of high past flow corporate bond funds. For growth funds, I find outperformance of the middle deciles over the outer deciles in both panels, whereas I find a significant relation only in Panel C for municipal bond funds. Panels E and F show results for flow-deciles ranked by relative flows lagged five and six months, respectively, but results show no systematic relationship and only weak evidence for outperformance of high past flow mortgagebacked bond funds.

In a similar fashion Table 6A reports performance and performance differences of deciles ranked by past absolute fund flows. For flows lagged one month, Panel A shows significant outperformance of high past flow deciles for mortgage-backed, municipal and general bond funds, as well as for growth funds and money market funds. Panel B, which reports results for deciles ranked by absolute flows lagged two months, shows significant outperformance of high past flow deciles for mortgage-backed and general bond funds, but no significant results for equity or money market funds. The remaining panels for deciles ranked by absolute flows lagged more than two months show most unsystematic results with the exception of significant outperformance of high past flow corporate bond funds in Panel $\mathrm{D}$. As the absolute flow results are similar in direction but weaker in significance than the relative flow results, I do not present Table 6a here, but it is available on request.

From these results I conclude that there is significant information about future returns in the flows to at least some fund groups. Especially high inflow mortgage-backed bond funds and general bond funds show significant outperformance. In addition, corporate bond fund flows provide some information. As for equity funds the information content is weak.

\section{4. "Flow Chasing” Investment Strategies}

In this section, I test whether the information content in fund flows regarding future returns can be exploited using simple investment algorithms. To do so, I compare the returns for four different strategies, two of which are uninformed and two that are informed. One strategy rebalances monthly the full sample of a respective fund group, one buys and holds the funds existing in a specific fund group at the beginning of the sample period ("initial funds”, e.g., Rohleder et al. [44]), and two invest according to past flow ranking information. All of these strategies account for front-end and rear-end loads charged for rebalancing transactions. 
Of the flow-decile-based algorithms, strategy three initially invests in flow-decile 10 (highest past flows) and replaces monthly the funds that have migrated to deciles lower than 8, so that after a warm-up period there are stable weights of deciles 8,9 , and 10 in the portfolio as well as a constant monthly turnover ratio. Strategy four replaces funds that have migrated to deciles lower than 8 only every second month in order to reduce load payments. In this way, again after a warm-up period, there are alternating but bi-monthly constant weights between all deciles in one month, or between deciles 8 , 9, and 10 in the other month, respectively, as well as a bi-monthly constant turnover ratio.

For both strategies, I calculate the portfolio weights and the turnover ratios from the empirical monthly and bi-monthly migration matrices. As an example, Table 7 shows the migration rates between relativeflow deciles for all small-cap equity funds. Variances and standard deviations are calculated using the empirical covariances between the flow-decile returns and the portfolios weights of the strategies. An illustration of the strategies and the covariance matrix of small-cap funds is given in the Appendix.

Table 7. Empirical migration matrices between flow deciles, small-cap equity funds.

\begin{tabular}{cccccccccccc}
\hline $\begin{array}{c}\text { Decile }(\boldsymbol{t}+\mathbf{1}) \\
\text { Decile (t) }\end{array}$ & $\mathbf{1}$ & $\mathbf{2}$ & $\mathbf{3}$ & $\mathbf{4}$ & $\mathbf{5}$ & $\mathbf{6}$ & $\mathbf{7}$ & $\mathbf{8}$ & $\mathbf{9}$ & $\mathbf{1 0}$ \\
\hline \multicolumn{8}{c}{ A. Empirical 1-month migration matrix } \\
\hline 1 (lowest) & 29.32 & 15.69 & 8.75 & 7.05 & 5.93 & 5.53 & 4.97 & 5.62 & 5.86 & 11.28 \\
2 & 17.29 & 25.54 & 17.29 & 10.28 & 7.60 & 5.53 & 5.09 & 4.28 & 4.22 & 2.88 \\
3 & 10.24 & 17.80 & 23.36 & 16.47 & 10.06 & 7.36 & 5.44 & 4.10 & 2.80 & 2.37 \\
4 & 6.91 & 11.17 & 17.07 & 21.05 & 15.87 & 10.45 & 6.67 & 5.21 & 2.94 & 2.65 \\
5 & 6.03 & 7.60 & 11.04 & 16.89 & 19.69 & 15.86 & 10.11 & 6.23 & 3.65 & 2.92 \\
6 & 5.31 & 6.22 & 7.46 & 10.52 & 16.83 & 20.01 & 15.44 & 9.46 & 5.41 & 3.34 \\
7 & 5.47 & 4.99 & 5.47 & 7.80 & 10.46 & 16.08 & 20.94 & 16.01 & 8.54 & 4.23 \\
8 & 5.72 & 4.52 & 4.13 & 4.78 & 6.81 & 9.83 & 17.22 & 23.68 & 16.63 & 6.68 \\
9 & 6.27 & 3.91 & 3.51 & 3.13 & 4.15 & 5.78 & 9.05 & 17.79 & 30.53 & 15.88 \\
10 (highest) & 8.13 & 3.01 & 2.20 & 2.16 & 2.62 & 3.47 & 4.87 & 7.36 & 19.03 & 47.15 \\
\hline \multicolumn{7}{c}{ B. Empirical 2-month migration matrix } & & & \\
\hline 1 (lowest) & 26.59 & 16.19 & 9.65 & 7.35 & 6.56 & 5.49 & 5.51 & 5.79 & 6.31 & 10.54 \\
2 & 17.42 & 23.67 & 17.15 & 11.25 & 7.41 & 6.43 & 5.44 & 4.36 & 3.71 & 3.15 \\
3 & 10.69 & 17.36 & 21.56 & 16.06 & 10.53 & 7.73 & 5.75 & 4.51 & 3.07 & 2.74 \\
4 & 8.13 & 11.05 & 16.50 & 19.82 & 14.83 & 10.33 & 7.32 & 5.11 & 3.66 & 3.24 \\
5 & 6.81 & 8.06 & 11.56 & 15.97 & 18.59 & 14.85 & 9.76 & 6.78 & 4.37 & 3.25 \\
6 & 6.31 & 6.57 & 8.07 & 10.47 & 15.48 & 18.55 & 14.88 & 9.80 & 5.94 & 3.94 \\
7 & 6.03 & 4.84 & 5.39 & 7.85 & 11.07 & 15.39 & 18.84 & 15.46 & 9.86 & 5.27 \\
8 & 5.54 & 5.06 & 4.06 & 5.11 & 7.40 & 10.41 & 16.87 & 21.78 & 16.26 & 7.51 \\
9 & 5.67 & 4.55 & 3.62 & 3.56 & 4.94 & 6.63 & 9.85 & 17.58 & 27.32 & 16.28 \\
10 (highest) & 7.49 & 3.09 & 2.72 & 2.69 & 3.21 & 4.15 & 5.63 & 8.49 & 19.08 & 43.45 \\
\hline
\end{tabular}

This table shows empirical migration rates between monthly rebalanced relative flow deciles of small-cap equity funds in the period from January 1993 through December 2009. Panel A shows migration rates within 1 month. Panel B shows migration rates within 2 months. Migration rates are denoted in \%.

Table 8 shows average loads per transaction and returns for the four investment strategies in the period from January 1993 through December 2009. Regarding the loads, bond funds charge lower loads on average than equity funds. Money market funds charge almost no loads. Front-end loads are distinctly higher than rear-end loads. The average front-end load for bond and equity funds range from $0.8634 \%$ of the amount invested for government bond funds to $1.3868 \%$ for aggressive growth funds. 
Table 8. Returns to different investment strategies and loads.

\begin{tabular}{|c|c|c|c|c|c|c|c|c|c|c|c|c|c|c|c|c|c|}
\hline & & & & \multicolumn{14}{|c|}{ Investment Strategies } \\
\hline & \multicolumn{3}{|c|}{ Average Loads per Transaction } & \multicolumn{4}{|c|}{ 1. All Funds Rebalanced Monthly } & \multicolumn{2}{|c|}{$\begin{array}{l}\text { 2. Buy and Hold } \\
\text { Initial Funds }\end{array}$} & \multicolumn{4}{|c|}{ 3. Flow Deciles Rebalanced Monthly } & \multicolumn{4}{|c|}{ 4. Flow Deciles Rebalanced Bi-Monthly } \\
\hline & Frond & Rear & $\begin{array}{c}\text { Round } \\
\text { Trip }\end{array}$ & MER & $\begin{array}{c}\text { MER - } \\
\text { Loads } \\
\end{array}$ & $\begin{array}{c}\text { Turnover } \\
\text { Ratio }{ }^{*,+} \\
\end{array}$ & St.dev. & MER & St.dev. & MER & $\begin{array}{c}\text { MER - } \\
\text { Loads }\end{array}$ & $\begin{array}{c}\text { Turnover } \\
\text { Ratio * }\end{array}$ & St.dev. & MER & $\begin{array}{c}\text { MER - } \\
\text { Loads } \\
\end{array}$ & $\begin{array}{c}\text { Turnover } \\
\text { Ratio ** }\end{array}$ & St.dev. \\
\hline \multicolumn{18}{|c|}{ Bond funds } \\
\hline All & 0.9146 & 0.3645 & 1.2791 & 0.1308 & 0.1227 & 0.63 & 0.9571 & 0.1309 & 1.0138 & 0.2149 & -0.2462 & 36.05 & 0.9298 & 0.1960 & -0.0511 & 38.63 & 0.9485 \\
\hline Corporate & 0.8865 & 0.3345 & 1.2211 & 0.1567 & 0.1478 & 0.73 & 1.0419 & 0.1531 & 1.2112 & 0.2408 & -0.2272 & 38.32 & 1.0524 & 0.2234 & -0.0225 & 40.27 & 1.0920 \\
\hline Government & 0.8634 & 0.3277 & 1.1912 & 0.1153 & 0.1089 & 0.54 & 0.9356 & 0.1323 & 0.9832 & 0.1447 & -0.3705 & 43.25 & 0.9805 & 0.1414 & -0.1272 & 45.10 & 0.9555 \\
\hline MBS & 0.9739 & 0.3221 & 1.2960 & 0.1596 & 0.1538 & 0.44 & 0.7510 & 0.1433 & 0.7758 & 0.2191 & -0.2130 & 33.34 & 0.8865 & 0.2020 & -0.0271 & 35.36 & 0.8520 \\
\hline Municipal & 0.9778 & 0.4127 & 1.3906 & 0.0922 & 0.0858 & 0.46 & 1.2017 & 0.1045 & 1.2647 & 0.1190 & -0.3530 & 33.94 & 0.9562 & 0.1116 & -0.1415 & 36.41 & 1.0108 \\
\hline General & 0.9451 & 0.6766 & 1.6217 & 0.1694 & 0.1462 & 1.43 & 1.3899 & 0.1399 & 1.4423 & 0.2818 & -0.1601 & 27.25 & 1.3979 & 0.2642 & 0.0143 & 30.82 & 1.4060 \\
\hline \multicolumn{18}{|c|}{ Equity funds } \\
\hline All & 1.2537 & 0.3935 & 1.6472 & 0.4036 & 0.3849 & 1.13 & 4.5269 & 0.3814 & 4.4598 & 0.4656 & -0.0151 & 29.18 & 4.9602 & 0.4516 & 0.1957 & 31.06 & 4.8085 \\
\hline Aggr. Gr. & 1.3868 & 0.4596 & 1.8464 & 0.3647 & 0.3412 & 1.27 & 4.7550 & 0.3926 & 5.0633 & 0.4843 & -0.0752 & 30.30 & 5.3015 & 0.4635 & 0.1525 & 33.70 & 5.1313 \\
\hline Growth & 1.3573 & 0.3756 & 1.7329 & 0.3334 & 0.3132 & 1.16 & 4.5397 & 0.3393 & 4.5149 & 0.3772 & -0.1336 & 29.48 & 5.0829 & 0.3728 & 0.1024 & 31.21 & 4.9237 \\
\hline Gr./Income & 1.2020 & 0.3679 & 1.5700 & 0.3530 & 0.3372 & 1.01 & 4.0211 & 0.3426 & 4.0382 & 0.4001 & -0.0310 & 27.26 & 4.0759 & 0.3965 & 0.1741 & 28.33 & 4.0507 \\
\hline Mid-Cap & 1.2445 & 0.4284 & 1.6728 & 0.5165 & 0.4876 & 1.73 & 5.2671 & 0.4057 & 5.4806 & 0.7627 & 0.2100 & 33.04 & 5.7144 & 0.7077 & 0.4196 & 34.44 & 5.6198 \\
\hline Small-Cap & 1.1057 & 0.4202 & 1.5260 & 0.5643 & 0.5478 & 1.08 & 5.4632 & 0.5232 & 5.3911 & 0.7530 & 0.2727 & 31.47 & 5.6719 & 0.7005 & 0.4409 & 34.03 & 5.6234 \\
\hline \multicolumn{18}{|c|}{ Money market funds } \\
\hline Money M. & 0.0359 & 0.0822 & 0.1181 & -0.0272 & -0.0276 & 0.34 & 0.0341 & -0.0326 & 0.0341 & 0.0029 & -0.0739 & 65.00 & 0.0312 & -0.0006 & -0.0390 & 65.00 & 0.0314 \\
\hline
\end{tabular}

This table shows average loads, mean excess returns (MER) for four investment strategies, and the turnover ratios of these investment strategies for different fund groups in the period from January 1993 through December 2009. Average loads are denoted in \% of invested money amount per transaction. Round trip represents the load associated with substituting a fund from the portfolio with another fund. All return measures are denoted in \% p.m. Turnover ratios are denoted in \% per month (*) or in \% per two months $(* *)$, respectively. "MER - Loads” are calculated as MER minus (monthly turnover ratio * round trip load). Strategy 1 rebalances monthly the returns of all funds available ( ${ }^{+}$the turnover ratio only accounts for buying the newborn funds but ignores rebalancing within the portfolio). Strategy 2 buys all funds initially existing in January 1993 and holds these through December 2009. Strategy 3 substitutes monthly all funds that have migrated to flow-deciles lower than 8 by funds ranked in decile 10. Strategy 4 rebalances bi-monthly the funds that have migrated to flow-deciles lower than 8 by funds ranked in decile 10 . "St. dev." is the standard deviation, "MER" is the mean excess return. 
The table shows a very clear picture of the investment strategies. Compared to the uninformed strategies, both flow-decile-based strategies show superior-or abnormal-returns before loads are accounted for. At the same time, the standard deviations do not change significantly, so that these strategies earn higher returns facing the same risk as the uninformed strategies. However, after loads are accounted for the table shows underperformance of the investment algorithms indicating that the abnormal returns are over-compensated by the associated loads charges.

It is, therefore, not possible to exploit the information content in lagged flows via these simple investment strategies. Of the two uninformed strategies neither is superior to the other. Strategy 1 yields the highest return for MBS, general bond, mid-cap, and small-cap funds. Strategy 2 shows the highest return for corporate, government, and municipal bond funds as well as for aggressive growth, growth, and growth/income funds.

Noteworthy is the fact that the highest abnormal returns from investing on past flow information are shown for small-cap and mid-cap funds. This is because, first, the flow-decile results in Table 6 are less significant for these fund groups than for bond funds and, second, because from a theoretical point of view funds investing in small-cap or mid cap-funds based upon past-flow data should not do well because these are considered to be less liquid than other equity funds.

\section{Conclusions}

In the mutual fund literature, the relationship between flows and performance is a widely discussed topic. There is a consensus that investors chase past performance, but the opposite direction is not as clear. I, therefore, investigate the relationship between past flows and future performance for a variety of bond, equity, and money market funds, as well as examine related economic issues like performance persistence and the size-performance relationship. I find clear evidence for economies of scale in the mutual fund industry, especially for bond and money market funds, but also to a lesser extent for equity funds. Moreover, I find short-term persistence for all fund groups as well as performance persistence over several months for money market funds.

Overall, these results lead to the conclusion that funds with high past inflow significantly outperform funds with low past inflow. This is especially true for mortgage-backed and general bond funds over several months. For equity funds, however I do not find significant results over more than one month. Based on this information, I used simple investment algorithms and find abnormal returns to these strategies for all fund groups, where the highest abnormal returns are possible for mid-cap and small-cap equity funds, as well as for general and corporate bond funds. At the same time, the standard deviations remain more or less unchanged. However, when Account for the load charges associated with these algorithms, the abnormal returns are so eaten up that simple informed investment strategies underperform uninformed strategies.

As a policy implication, I must advise against "Flow Chasing" as an investment strategy. My empirical results show that there is some informational content in past flows that are relevant to the future performance of funds. However, this is not sufficient to offset the transaction costs associated with "chasing” and acting on this information. 


\section{Acknowledgments}

I thank Marco Wilkens, Hendrik Scholz, Dominik Schulte and two anonymous reviewers for extraordinary helpful comments and suggestions. In addition, I would like to thank Franz Lutz and Janko Thyson for highly appreciated technical support. Further, I thank Michaela Goller and Elisabeth Hanisch for valuable administrative assistance. This research is part of my Ph.D. thesis, and was mostly done during my time at the Catholic University of Eichstaett-Ingolstadt. I am responsible for any remaining errors.

\section{Appendix}

Investment Strategies Based on Flow-Deciles with the Example of Small-Cap Equity Funds

Investment strategy 3 is based on substituting monthly the funds that have migrated to deciles lower than 8 with funds ranked in flow-decile 10. Portfolio turnover and weights are shown in Table A1.

Table A1. Strategy 3-Small-cap equity funds.

\begin{tabular}{|c|c|c|c|c|c|c|}
\hline \multirow[b]{2}{*}{ Month } & \multicolumn{2}{|c|}{ Portfolio Turnover } & \multicolumn{4}{|c|}{ Portfolio Composition } \\
\hline & Substitution & Turnover & Decile & Weight & Decile Return & Weighted Return \\
\hline \multirow[t]{4}{*}{$t-7$} & & & D8 & 0.00 & 0.7513 & 0.00 \\
\hline & & & D9 & 0.00 & 0.6244 & 0.00 \\
\hline & & & D10 & 100.00 & 0.7938 & 0.7938 \\
\hline & & & & 100.00 & & 0.7938 \\
\hline \multirow[t]{4}{*}{$t-6$} & $\mathrm{D} 1-7 \rightarrow \mathrm{D} 10$ & 26.46 & D8 & 7.36 & 0.7513 & 0.0553 \\
\hline & & & D9 & 19.03 & 0.6244 & 0.1188 \\
\hline & & & D10 & 73.61 & 0.7938 & 0.5843 \\
\hline & & 26.46 & & 100.00 & & 0.7584 \\
\hline \multirow[t]{4}{*}{$t-5$} & $\mathrm{D} 1-7 \rightarrow \mathrm{D} 10$ & 30.19 & D8 & 10.55 & 0.7513 & 0.0792 \\
\hline & & & D9 & 21.04 & 0.6244 & 0.1314 \\
\hline & & & D10 & 68.41 & 0.7938 & 0.5430 \\
\hline & & 30.19 & & 100.00 & & 0.7537 \\
\hline \multirow[t]{4}{*}{$t-4$} & $\mathrm{D} 1-7 \rightarrow \mathrm{D} 10$ & 31.22 & D8 & 11.28 & 0.7513 & 0.0847 \\
\hline & & & D9 & 21.20 & 0.6244 & 0.1324 \\
\hline & & & D10 & 67.53 & 0.7938 & 0.5360 \\
\hline & & 31.22 & & 100.00 & & 0.7531 \\
\hline \multirow[t]{4}{*}{$\geq t 0$} & $\mathrm{D} 1-7 \rightarrow \mathrm{D} 10$ & 31.47 & D8 & 11.44 & 0.7513 & 0.0859 \\
\hline & & & D9 & 21.19 & 0.6244 & 0.1323 \\
\hline & & & D10 & 67.37 & 0.7938 & 0.5348 \\
\hline & & 31.47 & & 100.00 & & 0.7530 \\
\hline
\end{tabular}

This table shows the warm-up phase $(<t 0)$ of strategy 1 as well as the constant (bold) portfolio weights, portfolio return and turnover ratio in and after $t 0$ for small-cap funds. Returns are denoted in \% p.m., weights are denoted in \%, and turnover is denoted in \% p.m.

The variance in the strategy portfolio is calculated using the empirical covariances between the flow-decile returns and the portfolio weights shown in Table A2. 
Table A2. Flow-decile covariances, small-cap equity funds.

\begin{tabular}{ccccccccccc}
\hline & D1 & D2 & D3 & D4 & D5 & D6 & D7 & D8 & D9 & D10 \\
\hline D1 & 0.32 & & & & & & & & & \\
D2 & 0.30 & 0.30 & & & & & & & & \\
D3 & 0.30 & 0.30 & 0.30 & & & & & & & \\
D4 & 0.30 & 0.29 & 0.30 & 0.31 & & & & & & \\
D5 & 0.31 & 0.29 & 0.30 & 0.30 & 0.31 & & & & & \\
D6 & 0.30 & 0.29 & 0.29 & 0.30 & 0.30 & 0.32 & & & & \\
D7 & 0.32 & 0.30 & 0.30 & 0.31 & 0.32 & 0.32 & 0.35 & & & \\
D8 & 0.32 & 0.29 & 0.30 & 0.31 & 0.32 & 0.32 & 0.34 & 0.35 & & \\
D9 & 0.31 & 0.29 & 0.29 & 0.30 & 0.31 & 0.31 & 0.32 & 0.33 & 0.32 & \\
D10 & 0.30 & 0.28 & 0.29 & 0.30 & 0.31 & 0.31 & 0.32 & 0.33 & 0.32 & 0.32 \\
\hline
\end{tabular}

Investment strategy 4 is based on substituting only every second month the funds that have migrated to deciles lower than 8 with funds ranked in flow-decile 10, as demonstrated in Table A3.

Table A3. Strategy 4-Small-cap equity funds.

\begin{tabular}{|c|c|c|c|c|c|c|}
\hline \multirow[b]{2}{*}{ Month } & \multicolumn{2}{|c|}{ Portfolio Turnover } & \multicolumn{4}{|c|}{ Portfolio Composition } \\
\hline & Substitution & Turnover & Decile & Weight & Decile Return & Weighted \\
\hline \multirow[t]{11}{*}{$t-8$} & & & D1 & 0.00 & 0.3242 & 0.0000 \\
\hline & & & D2 & 0.00 & 0.4108 & 0.0000 \\
\hline & & & D3 & 0.00 & 0.3720 & 0.0000 \\
\hline & & & D4 & 0.00 & 0.5437 & 0.0000 \\
\hline & & & D5 & 0.00 & 0.5264 & 0.0000 \\
\hline & & & D6 & 0.00 & 0.5612 & 0.0000 \\
\hline & & & D7 & 0.00 & 0.5131 & 0.0000 \\
\hline & & & D8 & 0.00 & 0.7513 & 0.0000 \\
\hline & & & D9 & 0.00 & 0.6244 & 0.0000 \\
\hline & & & D10 & 100.00 & 0.7938 & 0.7938 \\
\hline & & & & 100.00 & & 0.7938 \\
\hline \multirow[t]{11}{*}{$t-7$} & & & D1 & 8.13 & 0.3242 & 0.0264 \\
\hline & & & D2 & 3.01 & 0.4108 & 0.0124 \\
\hline & & & D3 & 2.20 & 0.3720 & 0.0082 \\
\hline & & & D4 & 2.16 & 0.5437 & 0.0117 \\
\hline & & & D5 & 2.62 & 0.5264 & 0.0138 \\
\hline & & & D6 & 3.47 & 0.5612 & 0.0195 \\
\hline & & & D7 & 4.87 & 0.5131 & 0.0250 \\
\hline & & & D8 & 7.36 & 0.7513 & 0.0553 \\
\hline & & & D9 & 19.03 & 0.6244 & 0.1188 \\
\hline & & & D10 & 47.15 & 0.7938 & 0.3742 \\
\hline & & & & 100.00 & & 0.6653 \\
\hline
\end{tabular}


Table A3. Cont.

\begin{tabular}{|c|c|c|c|c|c|c|}
\hline \multirow[b]{2}{*}{ Month } & \multicolumn{2}{|c|}{ Portfolio Turnover } & \multicolumn{4}{|c|}{ Portfolio Composition } \\
\hline & Substitution & Turnover & Decile & Weight & Decile Return & Weighted \\
\hline \multirow[t]{11}{*}{$t-6$} & $\mathrm{D} 1 \rightarrow \mathrm{D} 10$ & 7.49 & D1 & 0.00 & 0.3242 & 0.0000 \\
\hline & $\mathrm{D} 2 \rightarrow \mathrm{D} 10$ & 3.09 & D2 & 0.00 & 0.4108 & 0.0000 \\
\hline & $\mathrm{D} 3 \rightarrow \mathrm{D} 10$ & 2.72 & D3 & 0.00 & 0.3720 & 0.0000 \\
\hline & $\mathrm{D} 4 \rightarrow \mathrm{D} 10$ & 2.69 & D4 & 0.00 & 0.5437 & 0.0000 \\
\hline & $\mathrm{D} 5 \rightarrow \mathrm{D} 10$ & 3.21 & D5 & 0.00 & 0.5264 & 0.0000 \\
\hline & $\mathrm{D} 6 \rightarrow \mathrm{D} 10$ & 4.15 & D6 & 0.00 & 0.5612 & 0.0000 \\
\hline & $\mathrm{D} 7 \rightarrow \mathrm{D} 10$ & 5.63 & D7 & 0.00 & 0.5131 & 0.0000 \\
\hline & & & D8 & 8.49 & 0.7513 & 0.0638 \\
\hline & & & D9 & 19.08 & 0.6244 & 0.1191 \\
\hline & & & D10 & 72.43 & 0.7938 & 0.5749 \\
\hline & & 29.00 & & 100.00 & & 0.7578 \\
\hline \multirow[t]{11}{*}{$t-5$} & & & D1 & 7.57 & 0.3242 & 0.0245 \\
\hline & & & $\mathrm{D} 2$ & 3.31 & 0.4108 & 0.0136 \\
\hline & & & D3 & 2.62 & 0.3720 & 0.0097 \\
\hline & & & D4 & 2.57 & 0.5437 & 0.0140 \\
\hline & & & D5 & 3.27 & 0.5264 & 0.0172 \\
\hline & & & D6 & 4.45 & 0.5612 & 0.0250 \\
\hline & & & D7 & 6.71 & 0.5131 & 0.0344 \\
\hline & & & D8 & 10.74 & 0.7513 & 0.0807 \\
\hline & & & D9 & 21.02 & 0.6244 & 0.1312 \\
\hline & & & D10 & 37.75 & 0.7938 & 0.2996 \\
\hline & & & & 100.00 & & 0.6500 \\
\hline \multirow[t]{11}{*}{ to } & D1 & 6.89 & D1 & 0.00 & 0.3242 & 0.0000 \\
\hline & D2 & 3.62 & $\mathrm{D} 2$ & 0.00 & 0.4108 & 0.0000 \\
\hline & D3 & 3.06 & D3 & 0.00 & 0.3720 & 0.0000 \\
\hline & D4 & 3.15 & D4 & 0.00 & 0.5437 & 0.0000 \\
\hline & D5 & 4.06 & D5 & 0.00 & 0.5264 & 0.0000 \\
\hline & D6 & 5.40 & D6 & 0.00 & 0.5612 & 0.0000 \\
\hline & D7 & 7.82 & D7 & 0.00 & 0.5131 & 0.0000 \\
\hline & & & D8 & 11.93 & 0.7513 & 0.0896 \\
\hline & & & D9 & 20.43 & 0.6244 & 0.1276 \\
\hline & & & D10 & 67.65 & 0.7938 & 0.5369 \\
\hline & & 34.01 & & 100.00 & & 0.7541 \\
\hline \multirow[t]{12}{*}{$t+1$} & & & D1 & 7.46 & 0.3242 & 0.0242 \\
\hline & & & D2 & 3.37 & 0.4108 & 0.0139 \\
\hline & & & D3 & 2.70 & 0.3720 & 0.0100 \\
\hline & & & D4 & 2.67 & 0.5437 & 0.0145 \\
\hline & & & D5 & 3.43 & 0.5264 & 0.0181 \\
\hline & & & D6 & 4.70 & 0.5612 & 0.0264 \\
\hline & & & D7 & 7.19 & 0.5131 & 0.0369 \\
\hline & & & D8 & 11.44 & 0.7513 & 0.0859 \\
\hline & & & D9 & 21.09 & 0.6244 & 0.1317 \\
\hline & & & D10 & 35.94 & 0.7938 & 0.2852 \\
\hline & & & & 100.00 & & 0.6469 \\
\hline & & & & & & 0.7005 \\
\hline
\end{tabular}

This table shows the warm-up phase $(<t 0)$ of strategy 2 as well as the constant (bold) portfolio weights, portfolio return and turnover ratio in and after $t 0$ for small-cap funds. Returns are denoted in \% p.m., weights are denoted in \%, and turnover is denoted in \% per 2 months. 


\section{Conflicts of Interest}

The author declares no conflict of interest.

\section{References}

1. Ivković, Z.; Weisbenner, S. “Old” Money Matters: The Sensitivity of Mutual Fund Redemption Decisions to Past Performance. Available online: http://ssrn.com/abstract=903792 (accessed on 21 January 2015).

2. Ivković, Z.; Weisbenner, S. Individual investor mutual fund flows. J. Financ. Econ. 2009, 92, 223-237.

3. Fulkerson, J.A.; Jordan, B.D.; Riley, T.B. Return chasing in bond funds. J. Fixed Income 2013, 22, 90-103.

4. Clements, J. Chasing performance: Investors pour money into hard-asset mutual funds. Wall Street J. East. Ed. 2006, 247, D1.

5. Gaffen, D. Rally gets boost as quarter's end leads to performance-chasing. Wall Street J. East. Ed. 2009, 253, C5.

6. Israelsen, C.L. Stop chasing performance. Financ. Plan. 2013, 43, 95-97.

7. Ippolito, R.A. Consumer reaction to measures of poor quality: Evidence from the mutual fund industry. J. Law Econ. 1992, 35, 45-70.

8. Chevalier, J.; Ellison, G. Risk taking by mutual funds as a response to incentives. J. Polit. Econ. 1997, 105, 1167-1200.

9. Sirri, E.R.; Tufano, P. Costly search and mutual fund flows. J. Financ. 1998, 53, 1589-1622.

10. Del Guercio, D.; Tkac, P.A. The determinants of the flow of funds of managed portfolios: Mutual funds vs. pension funds. J. Financ. Quant. Anal. 2002, 37, 523-557.

11. Shrider, D.G. Running from a bear: How poor stock market performance affects the determinants of mutual fund flows. J. Bus. Financ. Account. 2009, 36, 987-1006.

12. Gruber, M.J. Another puzzle: The growth in actively managed mutual funds. J. Financ. 1996, 51, 783-810.

13. Lynch, A.W.; Musto, D.K. How investors interpret past fund returns. J. Financ. 2003, 63, 20332058.

14. Huang, J.; Wei, K.D.; Yan, H. Participation costs and the sensitivity of fund flows to past performance. J. Financ. 2007, 62, 1273-1311.

15. Cashman, G.D.; Deli, D.N.; Nardari, F.; Villupuram, S. Investors do respond to poor mutual fund performance: Evidence from inflows and outflows. Financ. Rev. 2012, 47, 719-739.

16. Cashman, G.D.; Deli, D.N.; Nardari, F.; Villupuram, S. Investor behavior in the mutual fund industry: Evidence from gross flows. J. Econ. Financ. 2014, 38, 541-567.

17. Cohen, L.; Schmidt, B. Attracting flows by attracting big clients. J. Financ. 2009, 64, 2125-2151.

18. Holden, S.; van Derhei, J. Recent trends in 401(k) participants' asset allocations. J. Financ. Serv. Prof. 2010, 64, 76-88. 
19. Goda, G.S.; Manchester, C.F.; Sojourner, A.J. What will my account really be worth? Experimental evidence on how retirement income projections affect saving. J. Public. Econ. 2014, 119, 80-92.

20. Ferson, W.E.; Schadt, R.W. Measuring fund strategy and performance in changing economic conditions. J. Financ. 1996, 51, 425-461.

21. Berk, J.B.; Green, R.C. Mutual fund flows and performance in rational markets. J. Polit. Econ. 2004, 112, 1269-1295.

22. Green, J.T.; Hodges, C.W. The dilution impact of daily fund flows on open-end mutual funds. J. Financ. Econ. 2002, 65, 131-158.

23. Coval, J.; Stafford, E. Asset fire sales (and purchases) in equity markets. J. Financ. Econ. 2007, 86, 479-512.

24. Edelen, R.M.; Evans, R.; Kadlec, G.B. Scale Effects in Mutual Fund Performance: The Role of Trading Costs. Available online: http://ssrn.com/abstract=951367 (accessed on 21 January 2015).

25. Benson, K.L.; Faff, R.W.; Smith, T. The simultaneous relation between fund flows and returns. Aust. J. Manag. 2010, 35, 51-68.

26. Edelen, R.M. Investor flows and the assessed performance of open-end mutual funds. J. Financ. Econ. 1999, 53, 439-466.

27. Chen, J.; Hong, H.; Huang, M.; Kubik, J.D. Does fund size erode mutual fund performance? The role of liquidity and organization. Am. Econ. Rev. 2004, 94, 1276-1302.

28. Pollet, J.M.; Wilson, M. How does size affect mutual fund behavior? J. Financ. 2008, 63, 2941-2969.

29. Warther, V.A. Aggregate mutual fund flows and security returns. J. Financ. Econ. 1995, 39, $209-235$.

30. Edelen, R.M.; Warner, J.B. Aggregate price effects of institutional trading: A study of mutual fund flows and market returns. J. Financ. Econ. 2001, 59, 195-220.

31. Bhargava, V.; Konku, D.K. Equity mutual funds flows and stock price changes. Int. J. Financ. 2004, 16, 3142-3153.

32. Alexander, G.J.; Cici, G.; Gibson, S. Does motivation matter when assessing trade performance? An analysis of mutual funds. Rev. Financ. Stud. 2007, 20, 125-150.

33. Rakowski, D.; Wang, X. The dynamics of short-term mutual fund flows and returns: A time-series and cross-sectional investigation. J. Bank. Financ. 2009, 33, 2102-2109.

34. Rakowski, D. Fund flow volatility and performance. J. Financ. Quant. Anal. 2010, 45, 223-237.

35. Rohleder, M.; Schulte, D.; Wilkens, M. Management of flow risk in mutual funds. Available online: http://ssrn.com/abstract=2419143 (accessed on 21 January 2015).

36. Grinblatt, M.; Titman, S. Mutual fund performance: An analysis of quarterly portfolio holdings. J. Bus. 1989, 62, 393-416.

37. Grinblatt, M.; Titman, S. Performance measurement without benchmarks: An examination of mutual fund returns. J. Bus. 1993, 66, 47-68.

38. Hendricks, D.; Patel, J.; Zeckhauser, R. Hot hands in mutual funds: Short-run persistence of relative performance, 1974-1988. J. Financ. 1993, 58, 93-130.

39. Cornell, B.; Green, K. The investment performance of low-grade bond funds. J. Financ. 1991, 46, 26-48. 
40. Krimm, S.; Scholz, H.; Wilkens, M. The Sharpe ratio's market climate bias-Theoretical and empirical evidence from US equity mutual funds. J. Asset Man. 2012, 13, 227-242.

41. Breloer, B.; Scholz, H. Jensen Alpha and Market Climate. Available online: http://ssrn.com/abstract=2370501 (accessed on 21 January 2015)

42. Ter Horst, J.R.; Nijman, T.E.; Verbeek, M. Eliminating look-ahead bias in evaluating persistence in mutual fund performance. J. Empir. Financ. 2001, 8, 345-373.

43. Ter Horst, J.R.; Verbeek, M. Fund liquidation, self-selection, and look-ahead bias in the hedge fund industry. Rev. Financ. 2007, 11, 605-632.

44. Rohleder, M.; Scholz, H.; Wilkens, M. Survivorship bias and mutual fund performance: Significance, relevance, and methodical differences. Rev. Financ. 2011, 15, 441-474.

45. Rohleder, M.; Scholz, H.; Wilkens, M. Bond Fund Disappearance: What's Return Got to Do with It? Available online: http://ssrn.com/abstract=1864423 (accessed on 21 January 2015).

46. Evans, R.B. Mutual fund incubation. J. Financ. 2010, 65, 1581-1611.

47. Carhart, M.M. On persistence in mutual fund performance. J. Financ. 1997, 52, 57-82.

48. Blake, C.R.; Elton, E.J.; Gruber, M.J. The performance of bond mutual funds. J. Bus. 1993, 66, 371-403.

49. Jensen, M.C. The Performance of mutual funds in the period 1945-1964. J. Financ. 1968, 23, 389-416.

50. Fama, E.F.; French, K.R. Common risk factors in the returns on stocks and bonds. J. Financ. Econ. 1993, 33, 3-56.

51. Jegadeesh, N.; Titman, S. Returns to buying winners and selling losers: Implications for stock market efficiency. J. Financ. 1993, 48, 65-91.

52. Brown, S.J.; Goetzmann, W.N. Performance persistence. J. Financ. 1995, 50, 679-698.

53. Berk, J.B.; Tonks, I. Return Persistence and Fund Flows in the Worst Performing Mutual Funds; NBER Working Paper Series, Paper 13042; NBER: Cambridge, MA, USA, 2007. Available online: www.nber.org/papers/w13042 (accessed on 21 January 2015).

54. Newey, W.K.; West, K.D. A simple, positive semi-definite, heteroskedasticity and autocorrelation consistent covariance matrix. Econometrica 1987, 55, 703-708.

55. Bollen, N.P.B.; Busse, J.A. Short-term persistence in mutual fund performance. Rev. Financ. Stud. 2004, 18, 561-597.

56. Fama, E.; French, K. Size, value, and momentum in international stock returns. J. Financ. Econ. 2012, 105, 457-472.

57. Avramov, D.; Chordia, T. Asset pricing models and financial market anomalies. Rev. Financ. Stud. 2006, 19, 1001-1040.

58. Huehn, H.; Scholz, H. Alpha Momentum and Price Momentum. Available online: http://ssrn.com/abstract=2287848 (accessed on 21 January 2015).

(C) 2015 by the author; licensee MDPI, Basel, Switzerland. This article is an open access article distributed under the terms and conditions of the Creative Commons Attribution license (http://creativecommons.org/licenses/by/4.0/). 